\title{
LÆRER ALFRED TORPS OPTEGNELSER FRA ET OPHOLD I TØNDER
}

Udgivet ved Peter Kr. Iversen.

Alfred Anton Christensen Torp, som hans fulde navn var, er født i Nørre Sundby den 27, november 1896 som søn af skomager J. C. Torp og hustru Ane Johanne, f. Jensen. Han tog mellemskoleeksamen fra Nørre Sundby Realskole 1913 og var derefter " lærerlærling " et år ved byens kommuneskole, inden han 1914 begyndte den tre-årige uddannelse ved Ranum Statsseminarium. Han bestod her lærereksamen 1917 med en jæun god karakter (mg $\div$ ), og det er med henblik på hans senere virke ikke uinteressant at se, at han fik ug $i$ historie og mundtlig dansk, men mærkværdigvis kun $g+\mathbf{i}$ skriftlig dansk. Efter eksamen var han $i$ nogen tid vikar ved Nørre Sundby kommuneskole, var soldat og kom derefter i september 1919 til Korsør, hvor han var lærer ved en privatskole og ved Teknisk Skole. Stærkt sønderjysk interesseret, som han var, skrev han allerede ved nytårstid til Jacob Appel om at komme til Sønderjylland som lærer, og det lykkedes ham, således som han nærmere redegør for i sine optegnelser, at få ansættelse ved den tyske kommuneskole i Tønder - en overordentlig vanskelig stilling, som det krævede stor takt og dygtighed at bestride. Men Alfred Torp opnåede ikke blot at vinde sine tysksindede kollegers tillid og respekt; takket være fremragende pædagogiske evner, som ganske vist ikke havde givet sig synderligt udslag på hans eksamensbevis, vandt han i sjæelden grad også sine elevers hengivenhed - ja, mange af hans gamle elever vil hævde, at han var den lærer, der kom til at betyde mest for dem. Og dette til trods for, at både kolleger og elever vidste, at han på fremtrædende plads tog del i det danske politiske og kulturelle arbejde, ikke blot $i$ Tønder, men snart også i hele landsdelen.

Alfred Torp blev først i tyverne amtskolekonsulent Nic. Svendsens medhjælper på skoledirektionens kontor og fik ikke blot her mindretalsskolernes problemer at se $i$ en større sammenhæng, 
men prægedes naturligvis også af Svendsens liberale syn på mindretalslovgivningen og inspireredes af ham til at være med $i$ nationalt og folkeligt arbejde. Torp var af politisk opfattelse radikal, og som Det radikale Venstres repræsentant fik han 1925 sæde i 'Tønder byråd, hvor han på adskillige områder kom til at øve afgørende indflydelse, bl. a. ved bygningen af den nye kaserne og ved anlægget af Højbjerg plantage. Han gjorde endvidere en god indsats inden for bestyrelsen for Tønder Bibliotek i dettes vanskelige, første år. Han blev formand for Tønder amts Radikale Venstre, senere landsdelsformand og medlem af partiets hovedbestyrelse og forretningsudvalg; 1932 var han partiets kandidat ved folketingsvalget. Som partiets betroede tillidsmand i Nordslesvig fik han på mange områder efter 1929 stor indflydelse på regeringens stillingtagen til nordslesvigske spørgsmål. Nu og da var professor Aage Friis formidleren mellem ham og ledende radikale politikere, men han kontaktede også disse direkte, når han opholdt sig i København, eller når han traf sammen med dem ved internationale kongresser. Torp kom også tidligt med i den lille kreds af fremtrædende nordslesvigske mænd, som under fortrolige former drøftede nationale forhold og problemer, og velorienteret som han derved blev over stillingen $i$ grænselandet $i$ de vanskelige år i 20'erne og begyndelsen af 30'erne, fik hans ord ekstra vægt overfor de radikale venner i København. Han pegede vel som den første på, at der måtte gøres en indsats for at bringe god skuespilkunst til Nordslesvig, og meget interessant er det, at han i 1933, da truslen om invasion af irregulære styrker syd fra hang over hovedet, energisk tog initiativet til, at den militære grænsebevogtning forstærkedes ved oprettelsen af befalingsmandsskoler i de sønderjyske garnisonsbyer.

Mindretalsspørgsmål hjemme og ude havde hans store interesse, og han foretog i den anledning studierejser til Belgien, Estland, Letland, Polen, Czekoslovakiet og Balkan; også i mindretalskongresser deltog han. Om sine rejser har han udarbejdet udførlige, fortrolige rapporter, og på tryk har han udsendt en lille bog på .tysk om: Die Lage der nationalen Minderheiten in der Czechoslovakei. I Flensborg Avis og andre danske dagblade har han mere populært meddelt indtryk fra sine rejser.

Ved sin tragiske død ved et færdselsuheld i december 1933, da 


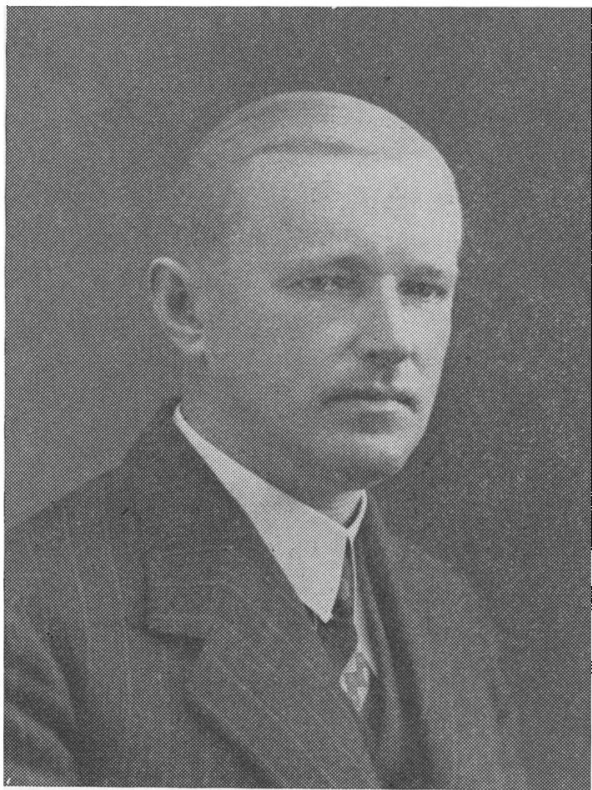

Alfred Torp

han var på vej til Åbenrå for at forhandle med H. P. Hanssen om at overtage en ledende stilling $i$ en planlagt national institution stod han på sit livs højdepunkt. Kun 37 år gammel blev han, og kun 13 år forundtes det ham at leve i den landsdel, som han havde viet sig selv og hele sin arbejdskraft til. Han forblev ugift, og det blev derfor en af hans nære venner, amtslæge, dr. H. Lausten Thomsen, der måtte drage omsorg for, at hans efterladte papirer blev afleveret til det netop oprettede landsarkiv i Åbenrå. Det har, som det ses af indledningen til Torps optegnelser, været hans hensigt før eller senere at offentliggøre dem, ja han har med henblik på trykning foretaget beregninger over deres omfang. Han har begyndt nedskrivningen af optegnelserne i 1923. Forordet er dateret 4. april 1923, og ved tilfældighedernes underfulde spil er den sidste indførsel dateret 4. april 1933. Det er ikke dagbogsoptegnelser $\mathrm{i}$ egentlig forstand. Kun når han har noget vigtigt at skrive om, eller når han har haft tid og lejlighed, har han grebet pennen. Trist er det, at han i den vigtige periode fra 11. november 1930 til 31. december 1932 ikke har haft tid til at skrive. 
Manuskriptet til Alfred Torps optegnelser er iøvrigt gengivet bogstavret, dog således, at der er anvendt små begyndelsesbogstaver i navneord i overensstemmelse med de nye retskrivningsregler. Endvidere er anvendt formerne kunne, skulle og ville, ligesom direkte skrivefejl er rettet. Enkelte uvæsentlige udeladelser er angivet ...., og hist og her er et navn af diskretionsgrunde erstattet med et bogstav. Optegnelserne følger i dette og følgende hæfter af Sønderjyske Årbøger. 


\section{Optegnelser fra et ophold i Tønder}

Nedskrevet af $A$. Torp, lærer ved Tønder tyske borgerskole.

Under et ophold $i$ Tonder $i$ tiden lige efter genforeningen bliver man vidne til mangt og meget, som ved straks at nedskrives burde bevares fra forglemmelse. Særlig i min egenskab af lærer ved Tønder tyske borgerskole har jeg oplevet en del, som jeg ofte har tænkt på at nedskrive, men mangel på tid har stadig afholdt mig derfra. Jeg har dog fastholdt tanken, thi selv om den slags optegnelser i tiden ofte synes ubetydelige, ikke mindst af den, der skriver, så ved jeg dog, hvor stærkt samtidige optegnelser af private mænd angående sønderjyske forhold kan virke, når de læses nu. Med største interesse læser jeg, hvad der i samtiden er skrevet om stemninger og tilstande i Sønderjylland, særlig sådant, som viser befolkningens stilling lige over for det danske i den tid, da modsætningsforholdet mellem dansk og tysk opstod. Nu er dette forhold siden genforeningen blevet aktuelt på en ny måde; ingen ved, hvorledes udviklingen vil blive for Danmark. Som den omstridte by Tønder er, må det siges, at udviklingen her vil være af særlig interesse, og hvad jeg på de følgende blade agter at optegne, håber jeg kan medvirke til for en del at levendegøre denne udvikling for fremtiden, idet jeg bemærker, at beretninger om de små dagligdags ting ikke er af mindst interesse; ofte har jeg selv ønsket at have haft sådanne samtidige skildringer fra det daglige liv for hundrede år siden fra gamle byer som Slesvig og Tønder, og selv de mindste af den slags småtræk har jeg læst med stor glæde.

Der er nu gået snart tre år, siden jeg kom til Tønder, og hvad jeg optegner fra denne periode, må jeg nu søge at samle sammen efter hukommelsen. Det meste står dog ganske klart for mig, kun vil det $\mathrm{i}$ det følgende måske gå lidt ud over den kronologiske rækkefølge, hvilket jeg dog mener er af mindre interesse, når det gælder om at redde et eller andet fra forglemmelse. Jeg håber i størst mulig grad at kunne undgå optegnelser, der kun er af 
personlig interesse (det er $i$ hvert fald mit ønske nu) og snarest at få skrevet så meget, at jeg kan komme til at få de forskellige ting nedskrevet, samtidigt med de sker.

Planen til dette lille arbejde har jeg som ovenfor nævnt længe haft, og når jeg nu skyder andet arbejde til side og tager fat, skyldes det særlig tilskyndelse fra amtsskolekonsulent Nicolai Svendsen, hvem jeg er takskyldig for så mange gode impulser.

F. t. Nørresundby, den 4 . april 1923.

A. Torp.

I genforeningsåret var jeg lærer i Korsør, men gjorde så snart som muligt skridt til at søge ansættelse i Sonderjylland; thi jeg ville føle det alt for fattigt, om jeg ikke direkte skulle komme med straks i den interessante tid, der forestod i Sønderjylland, men kun følge udviklingen på afstand; og hurtigt blev det mig klart, at mit ønske var at komme til Tønder. En regnvejrsdag. $i$ februar måned 1920 sendte kaptajn Eirs frue mig et nr. af $\rightarrow$ Flensborg Avis «, hvori der var en artikel, som den stærkt sønderjydsk interesserede frue onskede, at jeg skulle læse. Under læsningen faldt mit øje på en annonce, hvori Tønder by søgte en dansk lærer til byens folkeskole. Jeg skrev straks en ansagning om pladsen og håbede på det bedste; der gik imidlertid over en måned, hvori jeg intet hørte; jeg var derfor ved at miste troen på, at mit ønske denne gang skulle opfyldes. Da skete det, at jeg en søndag aften var $i$ selskab hos kaptajn Eirs; en dame spurgte mig da, om jeg så skulle til Tønder, hvortil jeg svarede, at det vidste jeg ikke endnu; i samme øjeblik kom jeg til at se i "Flensborg Avis *, der lå på bordet og læste en notits under bladets Tønder-rubrik; den lød således: »Skolevæsenet. Skolekommissionen har til undervisningsministeriet $i$ København indgivet andragende om, at førstelærer Hansen får overladt rektorstillingen ved borgerskolen i Richtsensgade. Kommissionen har ligeledes besluttet at ansætte lærer Torp fra Korsør som dansk lærer. ^

Dette var jo et meget morsomt tilfælde, og jeg sagde da: ,Ja, her står nu, at jeg er ansat «; alle tilstedeværende kom nu til, blev meget overraskede og onskede mig til lykke. Aftenen kom nu, i det smukt nationalt-prægede hjem, til at forløbe som en afskeds- 
fest for mig, så smukt, så jeg sent vil glemme det. Ved et glas vin onskede fru Eir al mulig held og lykke for mig i min fremtidige stilling $i$ det genvundne lands vanskeligste by.

Jeg regnede nu med snart at måtte modtage officiel meddelelse om min kaldelse, men jeg ventede længe forgæves. Først den 31. maj modtog jeg et brev, hvis konvolut var påtrykt et stort rundt stempel: >Commission Internationale Slesvig ‘. Selve brevet havde følgende ordlyd:

, Magistrat der Stadt Tondern,

Tondern, den 25. Mai 1920.

Wir teilen Ihnen hierduch ergebenst mit, dass Sie als Lehrer für den dänischen Sprachunterricht bei der hiesigen Volksschule gewählt sind. Ihre Vergütung regelt sich nach den nach der $\mathrm{Ab}$ tretung für Volkschullehrer geltenden Bestimmungen. Sie wollen umgehend mitteilen, wann Sie Ihre Stellung antreten können.

Oluf T. Olufsen.

An Herrn A. Torp,

Lehrer in Korsør, Dänemark.*

Jeg var naturligvis glad; thi nu havde jeg sikkerhed; ejendommeligt var det naturligvis som dansk lærer at modtage sit kaldsbrev på tysk; men det var for mig kun et vink om de særegne forhold, der ventede mig. Jeg trådte nu i forbindelse med Tønder by, men forskellige forhold bevirkede, at min tiltrædelse ikke kunne ske så hurtigt, og senere blev den udskudt til efter sommerferien, dog således at jeg skulle komme til byen, når ferien begyndte, for at træffe nærmere aftale angående arbejdet. I de to smukke sommermåneder, jeg endnu havde tilbage i Korsør, levede jeg fuldstændigt $i$ forventningen om den fremtid, der forestod mig i Tønder. Hvor jeg end færdedes, havde jeg Tønder $i$ tankerne og dannede mig mange forskellige forestillinger om min kommende virksomhed der; det kunne naturligvis ikke undgås, at mange af disse forestillinger, særlig da basis viste sig helt anderledes end tænkt, senere omstyrtedes; men alligevel står denne tid som en af den smukkeste del af mit liv.

Først i juli måned fik skolen sommerferie, og jeg begav mig da af sted på rejsen til Tønder for at blive sat ind $\mathrm{i}$ forholdene, 
der ventede, og som jeg på forhånd faktisk ikke kendte noget til. Turen gik over Nyborg-Fåborg til Sønderborg. På damperen fra Fåborg bemærkede jeg et større selskab af lærere, som efter deres samtale at dømme tydeligt nok var ude på en lignende rejse som jeg; det viste sig senere at være lærere, som efter ferien skulle virke ved den danske statsskole i Sønderborg. Ved seks tiden om eftermiddagen lagde damperen til ved Sønderborg havn. Byen stod fuldstændigt $i$ genforeningens festtegn, dagen $i$ forvejen var festligheden afsluttet - officielt, men byen var endnu øjensynligt i strålende feststemning, husene var smykket af tykke granguirlander, på gaderne var imponerende æresporte, og overalt var der en flagudsmykning, som man ikke kunne undgå at blive smittet af - der var høj luft. Jeg gik til jernbanestationen over pontonbroen, der endnu var en eneste flagalle. På perronen holdt toget til Tønder parat, hvor ejendommeligt at se et dansk tog holde her; i 1913 var jeg her sidste gang, da var alt tysk og tysk, og nu - danske vogne forspændt med et rødhalset lokomotiv, danske jernbanemænd, røde postbude og rundt om danske officerer. Jeg havde ellers ikke før følt mig opløftet ved at se danske officersuniformer på dette sted - her lige ved Dybbøl. Der var mange folk ved toget, og her som $\mathrm{i}$ byen gjorde en ganske mærkbar og smuk feststemning sig gældende. Som symbol for den nye tid vajede ovre på Als-siden på den store tidligere tyske marinekaserne et stort og prægtigt Danebrogs-flag. Toget holdt længe ud over den fastsatte afgangstid, inden det kørte; endelig, da alt var i orden, rullede vi af sted mod målet for min rejse mod Tønder. Rejsen blev langvarig og trættende, de danske myndigheder havde jo for nylig overtaget trafikken, og alt klappede endnu ikke ganske, opholdene på stationerne var ubehageligt lange, og selve kørselen var meget ubehagelig på grund af jernbanelegemets slette tilstand; i krigens sidste år var der jo så godt som ingen udbedringer sket. Først mellem 11 og 12, efter fem timers kørsel, nåede vi Tønder; jeg stod ud ved den første station og fik straks et utiltalende førstehåndsindtryk af byen; alt lå tilsyneladende $i$ uorden, og mørket herskede overalt, man kunne dårligt se, men en livlig ungdom skrålede tyske sange både på perronen og uden for stationen på den mørke plads. Det var således et ubehageligt indtryk, jeg som helt fremmed modtog af 


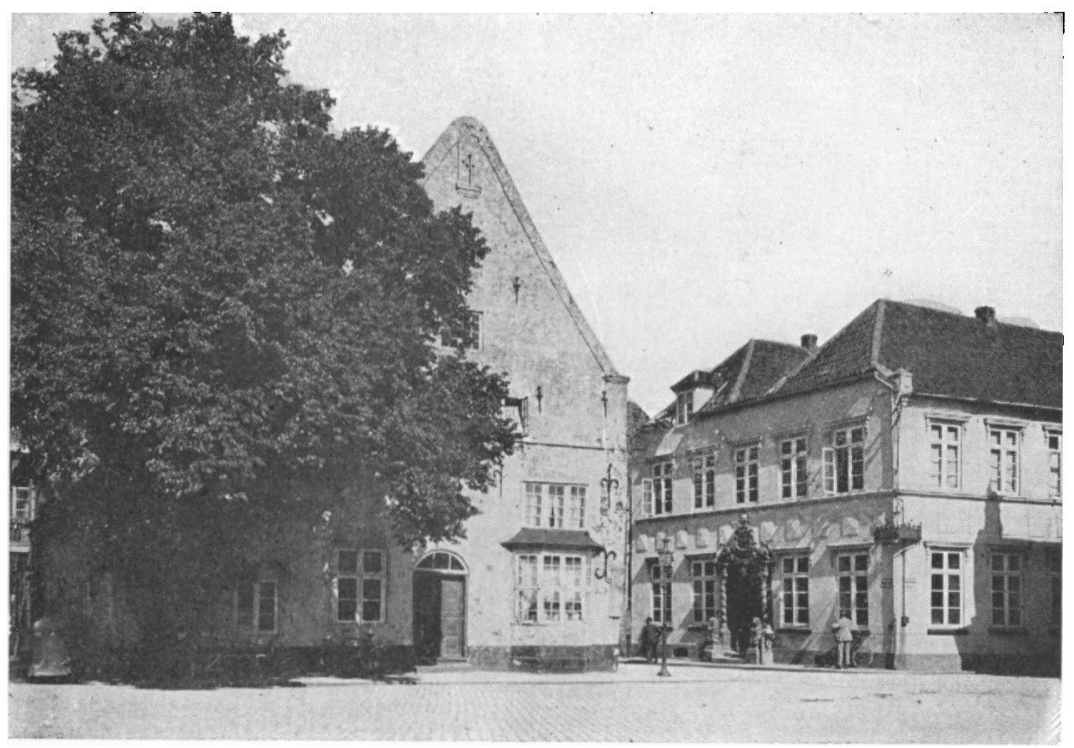

Store Torv $i$ Tonder med gavlhuset

byen, og for så vidt som der kun hørtes tysk, var det ikke opløftende for en vordende dansk lærer $\mathrm{i}$ byen. Min forste tanke var at finde et hotel for at få tag over hovedet. Et øjeblik efter ankomsten stod jeg i det nærliggende » Grand Hotel "s lokaler hvilken kontrast mødte mig ikke her til billedet fra banegården! Lokalerne festligt oplyst, pyntede, glade, dansktalende mennesker og et orkester, der spillede den ene nationalmelodi efter den anden, her følte jeg den samme stemning, som rådede i Sønderborg; kongen havde jo også lige været her og fået en smuk modtagelse af borgerne, der havde fået et godt indtryk af ham; de mange feststemte mennesker var dog overvejende tilrejsende folk, der var med til »genforeningen «. Et værelse var absolut ikke ledigt, "byen er aldeles oversvømmet af fremmede, det vil være absolut umuligt for Dem at opdrive et værelse i byen, gå hellere ned på banegården og læg Dem til at sove der i en 2. kl. kupe; det vil ikke blive Dem nægtet ". Således lød den modtagelse, jeg fik af tjenerne. Kopper og glas klirrede, og "Der er et yndigt land * lød ud over lokalerne. Jeg havde dog ingen lyst til at sove $i$ toget, 
men gik et stykke op ad gaden og kom til gæstgivergården •Børsen *. Jeg gik ind uden klart håb, men blev så meget mere glad, da værtens venlige hustru, fru Nicolaisen, meddelte mig, at der var plads til en gæst, når jeg ville dele værelse med en anden, der allerede var i seng, jeg modtog naturligvis tilbuddet, og et øjeblik efter var jeg i seng og sov ind - træt efter den lange dags mange indtryk. Det første, jeg næste morgen bemærkede, var min sovefælle. Han begyndte straks at udbrede sig om, hvad Tonder var for en slet by. Han var fra Sjælland, tømrer af profession, var hernede for at ordne en arvesag. Befolkningen bestod næsten kun af fanatiske tyskere, der ville lægge danskerne alle tænkelige hindringer i vejen. Han beklagede mig overordentligt, da han hørte, jeg skulle være lærer her i byen. Jeg skulle jo nu egentlig henvende mig til myndighederne, men det var lidt tidligt, og jeg besluttede mig derfor til først at se mig lidt om i byen. Hvor virkede alting dog ejendommeligt, særlig torvet med kirken og gavlhuset - et gammeldags malende billede af stor tiltrækning, - og så gaderne - snævre og krumme - med de gamle gavlhuse med karnapper - og sproget, man hørte på gaderne — dansk — rigsmålet og sønderjydsk - og tysk imellem hinanden. Byen var jo lige blevet dansk, og en hel del ydre ting mindede naturligvis om det tyske, men lige uden for »Børsen «s vinduer så jeg noget, der var dansk nok, her holdt nemlig de danske dragoner $i$ et par lange rækker ned over Torvet parate til udrykning. Jeg spadserede ned gennem byen — ad Østergade og kom ud ad Ribe-landevejen, snart var jeg ved den midlertidige soldaterlejr, hvor der ved vejen var udstillet et par vagtposter, infanterister; jeg kom lidt i samtale med dem; de var nu ganske godt tilfredse, men i de første dage havde det været mindre behageligt; mange handlende ville ikke sælge til dem, hvorfor de længe måtte leve af konserves, og om aftenen, når det var mørkt, kunne de ikke være sikre på gaden; en soldat var blevet overfaldet og skudt $i$ det ene ben; han lå nu på sygehuset. Jeg gik videre, kom ud til luftskibshallen, fra hvis tag jeg fik det første overblik over den egn, jeg senere skulle stifte så godt bekendtskab med. Da jeg senere var kommen tilbage til byen, gik jeg op og hilste på bankdirektør Rossen, hvem jeg havde rådført mig en del med. Han modtog mig meget hjerteligt, og jeg fik af hans person et stærkt indtryk af 
den feststemning, som genforeningsdagene havde bibragt det danske folk. Dernæst opsøgte jeg amtsskolekonsulent Svendsen i hans private bolig; han var imidlertid netop i dag til kongemiddag om bord på "Danebrog " i Åbenrå; i stedet for hilste jeg på hans hustru, der modtog mine papirer. Herefter bestemte jeg mig til at henvende mig til borgmesteren; det var egentlig med en vis ubehagelig følelse, jeg foretog dette skridt, der var jo fortalt så meget ilde om tyskerne i Tønder, og borgmesteren tænkte jeg mig uvilkårligt som en af de værste, i hvert fald var jeg forberedt på, at han var en studs herre, der talte tysk og ville forlange det samme af mig. Jeg blev imidlertid glædelig overrasket; borgmester Olufsen var ganske anderledes, end jeg havde tænkt mig; han talte dansk og spurgte mig meget elskværdigt ud om mine forhold, idet han satte sig ned $i$ sofaen ved siden af mig; samtalen varede en halv times tid, om enkeltheder vedrørende skolevæsenet ville han dog tilsyneladende ikke ind på, derimod spurgte han mig, om jeg ikke ville have et forskud på lønnen og lod af en assistent straks en anvisning på $400 \mathrm{kr}$. udstede; pengene kunne hæves på kæmnerkontoret i værelset ved siden af. Da jeg havde taget afsked med borgmesteren, gik jeg ind efter pengene; det var bemærkelsesværdigt, at assistenterne ikke endnu talte dansk ved betjeningen; i hvert fald blev jeg tiltalt på tysk. $\mathrm{Nu}$ da dette skrives, taler de samme personer endog dansk indbyrdes på kontoret, og kun tysk til sådanne folk, der taler dette sprog, når de kommer ind. På borgmesterens forslag besøgte jeg nu min fremtidige overlærer, C. P. Hansen. Skolen lå lige i nærheden i Richtsensgade, og jeg traf overlæreren på legepladsen sammen med en af de ældre lærere ved navn H. P. Hansen. Begge gjorde straks et godt indtryk, og efter at de første bemærkninger var vekslet, sagde overlæreren: ,Ja, hr. Torp, det er jo her, De skal være!« Ja, det mente jeg også, det var jo derfor, jeg kom. » Ja, men det her er jo den tyske skole, og De skal her være dansk lærer, altså i dansk sprog og er forresten den eneste fremmede, der kommer, de øvrige lærere er de gamle fra den tyske tid; men det skal De ikke være ked af, det skal nok gå «. Det var jo en ret forbløffende oplysning for mig, der var fuldstændig indstillet på at komme til en dansk skole og virke blandt børn, hvis forældre nu med glæde og tilfredshed sendte dem til dansk undervisning. 
Jeg gik imidlertid med de to mænd indenfor og fik en lang samtale, hvori jeg for første gang så det hele genforeningsspørgsmål set fra tysk standpunkt; lærerne var meget interesserede $\mathbf{i}$ at få oplysninger om danske skoleforhold; de var jo nu gået i en stats tjeneste, hvis forhold de kendte meget lidt til. Begge havde deltaget flere år $\mathbf{i}$ verdenskrigen og viste sig tydeligt at være meget moderate i deres tyskhed; jeg var ikke i tvivl om, at de ville være loyale over for Danmark i deres tjenesteforhold. Aftalen blev, at jeg nu skulle rejse til mit hjem i Nørresundby og blive hjemme, indtil overlæreren meddelte mig, at skolen kunne begynde, det ville blive omkring ved september; foreløbig var skolen belagt med danske soldater og jernbanefolk, der ikke kunne være andre steder i den forste tid. Overlæreren fulgte mig ud; ved et vindue i lejligheden på 1. sal stod en ældre herre, det var skolens tidligere rektor (overlærer), Petersen hed han, som på grund af sit tyske sindelag ikke ville gå i dansk tjeneste, og derfor nu flyttede til Tyskland for at overtage et embede i Kiel. Da jeg kom op på "Børsen" for at spise, sad der i restaurationen en ældre gråsprængt herre, som jeg blev forestillet for. Det var redaktør Becker ved "Tondernsche Zeitung", der nu var gået over til at være et dansksindet, men stadigt tyskskrevet blad. Han udbredte sig meget livligt og med stor begejstring på tysk om, hvor udmærket kongen havde været ved sit besøg dagen i forvejen i Højer. »So leutselig ", » so freundlich ", »so einfach " var nogle af de oftest forekommende udbrud $\mathrm{i}$ hans lovtale. Borgmester Johannsen havde holdt velkomsttale på tysk og mindet kongen om, at byens flertal som bekendt ikke havde onsket at komme til Danmark. Kongen havde da på en heldig måde udtrykt i sin svartale, at han jo vidste, hvordan forholdene var, og at det $i$ hvert fald glædede ham at træffe på ærlige folk, der ikke var tyske i går og danske i dag - Næste morgen rejste jeg hjem og holdt nu sommerferie et par måneder, rigt ladet med indtryk og med stærke forventninger til den formentlig interessante tid, der forestod.

Sidst i august meddelte overlærer Hansen mig, at skolen nu kunne begynde, og den 1 . september rejste jeg atter til Tønder. Den formiddag, jeg ankom, opsøgte jeg overlæreren, som på det tidspunkt underviste $i$ øverste drengeklasse; det var med megen interesse, jeg her stod overfor en af de klasser, jeg herefter dag- 
ligt skulle omgås, og det var tilsyneladende med ikke mindre interesse, at drengene betragtede mig, da de havde fảet at vide, at jeg var den danske lærer; alt hvad der kom fra »det gamle Danmark " var i de dage omgivet med megen interesse; men på forhând var man jo egentlig ikke forberedt på nogen venlig interesse. I afstemningstiden havde der lydt mange rygter om Tønders danskf jendtlighed, således at byen for mange var det sorte punkt i hele genforeningsglæden. Jeg havde også modtaget mange advarsler fra folk, som hørte om min fremtidige stilling, og selvfølgelig var jeg klar over, at jeg eventuelt ikke kunne klare opgaven, men forsøges skulle det og det af al kraft og energi. Nu stod jeg altså over for en klasse af de storste, de så egentlig meget tiltalende ud, der var ingen fjendtlige blikke at bemærke, og da jeg senere mødte enkelte af dem på gaden, hilste de mig overordentlig høfligt. Begyndelsen var således lovende.

Overlæreren satte mig nu lidt ind $\mathrm{i}$ forholdene; jeg skulle udelukkende undervise i dansk, fire timer i hver klasse fra 4. skoleårs begyndelse; deltagelsen fra børnenes side var tvangfri, d. v. s. forældrene kunne ved et skoleârs begyndelse forlange deres børn fritaget for danskundervisning, jeg var egentlig glad ved denne bestemmelse og har også senere overvejende fundet den heldig; efter alt, hvad man havde hørt om Tønder, var jeg forberedt på, at mange af forældrene ville benytte sig deraf; men det viste sig snart ikke at være tilfældet; vel havde der, som overlæreren fortalte, fra tyske forældre ofte lydt udtalelser som "Mein Kind soll kein Dänisch haben ", o. lign. Nu da det kom til stykket, viste det sig, at det var få, som ikke skulle have dansk, af skolens 465 elever var der ialt måske kun femten. Det var om lørdagen, og det blev nu bestemt, at jeg skulle optage undervisningen om mandagen. Jeg kunne så forinden orientere mig i byen, skaffe mig en bolig og hilse på forskellige folk, jeg kunne have interesse af at stifte bekendtskab med. Et par værelser at bo $i$ var det meget vanskeligt at få, omsider meddelte en af skolens lærerinder, frk. Christensen, mig, at jeg vistnok kunne bo $\mathrm{i}$ hendes moders hus på Torvet nr. 5 , selv boede hun hjemme hos sin mor. Jeg gik derhen og fik snart truffet aftale med de flinke folk. Lejen var nærmest lav, skønt man $i$ den tid kunne tage for værelser så meget, man næsten ville, i Tonder; men een betingelse blev der 
meget karakteristisk stillet, at jeg ikke måtte stille noget Danebrogsflag i vinduet. Dette var jo heller ikke nødvendigt, og jeg boede meget behageligt her $i$ over et år. Familien Christensen var af en gammel hjemmetysk slægt, der stammede fra Rørkær; hussproget var dansk; moderen kunne egentlig ikke rigtig tysk, og datteren erklærede engang over for mig, at det aldrig kunne falde hende ind at tale tysk med sin mor.

I løbet af lordagen fik jeg talt med forskellige af de tilflyttede embedsmænd. Seminarieforstander Albeck traf jeg på seminariet, hvor der efter indkvarteringerne af engelske og danske soldater endnu langtfra var bragt orden $i$ alt. Provst Christensen besøgte jeg søndag eftermiddag $i$ hans bolig ved kirken; ved samme lejlighed fik jeg hilst på postmester Nielsen, hvis hustru iøvrigt var fra Slesvig by.

Mandag morgen optog jeg - med stor forventning naturligvis — min gerning. På skolepladsen lidt før kl. $8 \mathrm{blev}$ jeg efterhånden af overlæreren forestillet for mine fremtidige kolleger, nemlig lærerne Lammers, M. M. Petersen, Gläser, Th. Jacobsen og Johannsen, samt lærerinderne A. Krogh, fru Grandt, H. Petersen, H. Kardel og Rathje. Senere kom til dette personale lærer Brochmann og lærerinde frk. Lytsen; den ældste af lærerne, H. P. Hansen, havde jeg som nævnt allerede lært at kende. Næsten alle var nordslesvigere, undtagelse var Lammers, der stammede fra Eckernførde, men i snart 25 år havde haft sin virksomhed i Nordslesvig (Als og Tønder), og fru Grandt, der var berliner, men enke efter en Tønder-skibskaplajn. Af disse to forstod Lammers dansk og kunne også tale sproget, men med stort besvær og gjorde det kun sjældent. Fru Grandt forstod sproget nogenlunde, men kunne slet ikke tale det. Frk. Rathje kunne kun tale "Tonder-dansk" og brugte derfor altid tysk; hun var datter af tidligere borgmester Rathje i Tønder. (Han havde deltaget i krigen 1864 på dansk side, men som supålidelig" var han sammen med flere andre sydslesvigere blevet holdt tilbage på Als under krigen). Alle de øvrige lærere og lærerinder talte mere eller mindre godt dansk. Jeg blev modtaget med megen venlighed af alle; de, der som ovenfor nævnt, kunne tale dansk, benyttede dette sprog i samtalen med mig både nu og senere. Børnene var tilsyneladende meget optaget af mig; da de tyske lærere alle var de gamle, var jeg jo 
den eneste til at markere den nye tid. Den forste time fik jeg i en 7. pigeklasse; jeg begyndte med at lade børnene synge en tysk morgensalme, som de selv valgte, hvorefter en af dem fremsagde morgenbønnen. Det gjorde øjensynligt straks et godt indtryk, at dette foregik på tysk; jeg sagde nu — på dansk naturligvis, (de danske timer skulle foregå på dansk) - nogle indledende ord, hvorefter vi straks tog fat på undervisningen. Begyndelsen skete med primitive midler; thi læsebøger havde man villet vente med at anskaffe, til jeg kom. Af en tysk bog fremsagde jeg sætninger for klassen, som børnene skulle oversætte til dansk; det syntes straks at interessere; de fleste markerede meget livligt og var hurtige til at svare; det, der således var blevet oversat, behandlede vi senere skriftligt. Da der således var gået en 14 dages tid, fik vi læsebøgerne. Nu bagefter beundrer jeg mig selv en lille smule for den uforfærdethed, hvormed jeg læste tysk for børnene; nu efter at der er gået tre år, er jeg mere forsigtig. Jeg må dog sige, at børnene ikke på nogen måde reagerede over mit tysk; forovrigt talte jeg også i den første tid adskilligt mere tysk med mine kolleger end nu - rent ubevidst. I timen fra 11 til 12 den første dag havde jeg undervisning i overlærerens kl. (7. dr.), hvori største delen var store drenge på 14 à 15 år. Jeg sagde også her et par ord til indledning og sluttede med at sige: >Jeg er ikke kommen for at gøre tyske drenge til danske drenge, men for at lære jer dansk, hvilket I under de nye forhold kan have megen gavn af «. Drengene syntes tilsyneladende at være meget tilfredse dermed, og senere fik jeg bekræftet, at det var en heldig begyndelse. Et par dage efter mødte jeg overlæreren på en af trappeopgangene; han sagde i samtalens løb, at jeg kunne være sikker på, at jeg i mange tyske hjem var et vigtigt samtaleemne i disse dage, og at jeg kunne være sikker på, at min adfærd og mine udtalelser over for børnene blev meget nøje overvåget; thi endnu var sindene mere eller mindre krigeriske. Men det glædede ham at kunne meddele mig, at min tiltale til drengene den første dag havde været heldig, børnene havde fortalt derom hjemme, og flere forældre havde overfor overlæreren udtrykt deres tilfredshed dermed.

Den første tid blev rig på forskelligartede indtryk, på mange punkter formede skolelivet sig anderledes her, end jeg havde 
været vant til. Forholdet til kolleger og elever blev fra første færd af godt, således at jeg nu, efter at der er gået tre år, ikke ville synes om at gøre forandring $i$ min virksomhed. Når de øvrige lærere talte til mig, var det altid på dansk, når det da ikke var lærere, der ikke kunne det, og fremførte jeg på lærerværelset eller $i$ et lærermøde et eller andet, blev samtalen ofte $i$ længere tid ført videre på dansk. Også selskabeligt kom jeg snart i godt forhold til flere af kollegerne, som, hvad der straks vil forstås, var fornuftige folk og ikke meget skarpe i deres tyskhed, hvorvel de alle med undtagelse af frk. Lytsen var tysksindede. Deres loyalitet over for Danmark blev jeg fra tid til anden mere og mere overbevist om. Børnene stillede sig meget korrekt over for mig; fra første færd tiltalte de mig kun på dansk, selv de der havde lidt svært ved det; jeg tror ikke, at det var efter ordre fra overlæreren, men noget som børnene rent instinktivt gjorde af sig selv. Kom der et barn ind fra en anden klasse $i$ min og skulle sige en besked og da talte tysk, lo de andre, som de ville sige: >Hvad tænker du på, komme her og tale tysk «. Jeg må forresten bemærke, at der i den første tid gik enkelte børn fra dansksindede hjem i skolen; det var i de fleste tilfælde born, der snart skulle konfirmeres, og som man af praktiske grunde ikke ville lade skifte skole. Mere mærkeligt er det, at der endnu tre år efter genforeningen vedblivende går ganske enkelte børn af danske forældre hos os, endog af sådanne forældre, der på alle nationale festdage hejser Danebrog.

Samarbejdet med børnene blev som nævnt godt, dog må jeg her nævne en undtagelse, nemlig 7. pigeklasse; efterhånden blev forholdet til den mindre godt, så at jeg ingen fornøjelse fik af undervisningen og måtte tage strengere fat, end jeg onskede, ligesom jeg pådrog mig adskillige ærgrelser. Jeg var gjort opmærksom på, at kvinderne $i$ den nationale kamp altid havde været mere iltre og fanatiske end mændene, og dette kunne allerede her spores på de store piger. De stillede sig tydeligt på vagt over for mig; da jeg en dag fortalte om udsagnsordenes måder og nævnede, at udråbet >kongen leve! « var et eksempel på ønskemåden, puffede en stor pige straks ivrigt til sin veninde, som ville hun sige: - Så, nu skal han til at agitere, at udbringe leve for kongen «. Heldigvis nævnede jeg i samme forbindelse og uden afbrydelse ud- 
trykket "kejseren leve", "dronningen leve " o. s. v. som eksempel på ønskemåden. Dermed blev der ikke stof til nogen "historie", og pigen så meget skuffet ud. En dag på kejser Wilhelms fødselsdag, kom jeg ind i klassen, og nogle af pigerne sagde da: "I dag er det vores kejsers fødselsdag, skal vi ikke have en historie Klassen skulle netop den dag skrive genfortælling, og jeg svarede derfor straks: "Jo, det skal I, og den skal I få straks», hvorefter jeg oplæste den historie, klassen skulle skrive. De fleste af dem smilte lidt flovt ved det resultat og forsøgte egentlig ikke senere noget lignende, når jeg undtager, at enkelte på den store tavle eller på trækpapiret $\mathrm{i}$ deres danske stilebøger demonstrativt tegnede tyske flag, hvad jeg naturligvis lod, som jeg ikke bemærkede. I stedet for forsøgte klassen ofte at udvise passiv modstand i undervisningen, der gav sig udslag i stadig urigtig læsning, ikke aflevering af stile $i$ rette tid, forstilt uforstån over for mine spørgsmål og derved, at de fleste ofte undlod at markere. Denne adfærd kan delvis tilskrives det, at en del af børnene med deres forældre skulle rejse til Tyskland $i$ den nærmeste fremtid og altså ikke var interesserede $i$ at lære dansk; de fleste af de øvrige skulle konfirmeres til foråret, hvilket naturligvis heller ikke fremmede deres interesse for undervisningen. Forholdet var som sagt mindre behageligt, jeg mátle have et øje på hver finger og beherske mig meget; jeg havde til at begynde med vist været for venlig, og venlighed var egentlig ikke netop det, der tiltrængtes i den klasse. Som eksempel på deres adfærd kan jeg nævne følgende: En stor pige sad og hang over bordet med hånden under hovedet. Uden at tænke stort over det, sagde jeg, at hun skulle tage hånden bort; hun gjorde det, men et øjeblik efter havde hun hånden der igen; jeg sagde igen det samme, men på en udfordrende trodsig måde kom hånden straks under hovedet igen. Sagen i sig selv var jo uden betydning, men her var kommen det alvorlige moment til, at der aldeles klart var udvist respektstridighed og trods; jeg sagde derfor ganske kort: „Når du ikke gør, som jeg siger, må du i eftermiddag sidde over efter skoletid ". Men nu kom det mindre behagelige, et øjeblik efter havde en anden pige hånden under hovedet, idet hun hoverende så sig om blandt veninderne. Hun måtte også sidde efter. Straks kom der en med hånden på samme måde. "Du må også sidde over i eftermiddag *, der kom 
nok en og med samme resultat; det skulle ábenbart forsøges, hvem der først blev træt; først da det viste sig, at jeg konsekvent uddelte eftersidningsstraf og for de sidsles vedkommende desuden skriftlig hjemmestil som straffearbejde, hørte forsøgene op. Heldigvis hørte disse ubehageligheder op til foråret 1921, da de fleste i klassen blev konfirmeret. Forholdet $i$ de andre klasser var som nævnt godt, og jeg har $\mathrm{i}$ de forløbne tre år kunnet glæde mig over $i$ en fra første færd af ganske uventet grad at have vundet børnenes fortrolighed og tillidsfuldhed, således at jeg har det indtryk, at de ikke skelner mellem mig og deres tyske lærere.

Samarbejdet med mine tyske kolleger var godt, og de understøttede min autoritet over for børnene på enhver måde. Jeg kan som eksempel herpå nævne følgende: En dag havde en større pigeklasse på grund af regnvejr fảet lov til at blive inde i klassen; de gav sig da til at opføre en sangleg, hvortil de sang SlesvigHolsten visen; lærer Hansen kom forbi og hørte det; da det udtrykkeligt var forklaret børnene, at den og visse andre sange ikke måtte synges $\mathrm{i}$ skolen, jog han dem op i deres egen klasse, hvor de mâtte blive i pausen; lærer Hansen irettesatte dem og sluttede med at sige, at on ikke af anden grund skulle de undlade at synge sangen af hensyn til lærer Torp, der kunne opfatte afsyngelsen som en udfordring mod sig. Jeg havde nu iøvrigt slet ikke været i nærheden.

En dag - også her i den forste tid - fik jeg en forespørgsel fra "To Løver" i København, om jeg blandt skolens elever ville forestå uddelingen af nogle danske bøger. Jeg var noget betænkelig derved, det kunne jo let udlægges forkert; jeg forelagde da overlæreren sagen, der imidlertid ikke havde det mindste derimod. Kun bad han mig påse, at der ikke uddeltes bøger, som af nationale grunde ikke egnede sig, hvad jeg naturligvis ikke mindst af hensyn til min egen stilling nok skulle sørge for.

Da bøgerne var kommen, spurgte overlæreren mig imidlertid, om jeg ikke hellere ville låne dem ud end forære dem bort, altså lave et lille bibliotek deraf. Jeg havde ikke et øjeblik tænkt, at noget sådant kunne finde sted på den tyske skole, men betænkte mig naturligvis ikke på at slå til. De ca. 50 bøger, der egnede sig, fik jeg opstillet $i$ et skab, og i 7. dr. sagde jeg da en dag, at hvis nogen ønskede en dansk bog hjem at læse $i$, kunne de melde sig, 
når det ringede; jeg udtalte naturligvis ikke den mindste anbefaling herfor; men da det ringede, meldte sig en stor part af drengene for at låne bøgerne, som nu snart alle kom i livlig cirkulation og blev læst -- det kontrollerede jeg fra første færd nøje. Dermed var det første danske bibliotek begyndt i Tønder - og det ved den tyske skole. Den danske folkeskole fik først en børnebogsamling omtrent et år senere, og et offentligt folkebibliotek ventes først åbnet $\mathrm{i}$ den kommende vinter (oktober 1923). Læselysten og evnen var imidlertid større, end jeg havde regnet med, og antallet af boger blev derfor snart for lille; fra forskellige steder fik jeg da betydelige boggaver, hvorved udlånet kunne udstrækkes til enkelte af de andre klasser; flere og flere meldte sig som lânere, ikke alene til sig selv, men også til forældrene; det hændte ofte, at et barn om middagen kom og spurgte: "Má jeg fâ en bog? ". "Ja, det mâ du nok; hvor har du den gamle? " "Ja, den er min far ikke helt færdig med, men jeg har læst den ", lød svaret ofte, og naturligvis fik vedkommende barn en bog. I en forbavsende ringe grad spillede det nationale ind i dette forhold; endog børn fra meget bevidst tyske hjem kom og lânte bøger til sig selv og forældrene. Efter som læsefærdigheden i tidens lob skred frem, udstrakte jeg udlånet til flere og flere klasser, men således skulle der jo også flere bøger til; skolen fik en dag besøg af midlertidig bibliotekar for Det sønderjydske Landsbibliotek, Carl S. Petersen, der straks blev interesseret i min slille biks", som han kaldte biblioteket, og han henstillede til mig at søge tilskud fra "Sprogforeningen" ved henvendelse til H. P. Hanssen; det samme opfordrede amtsskolekonsulent Svendsen mig til, og efter at have sendt en ansøgning til $H$. P. Hanssen og forklaret stillingen, fik jeg af "Sprogforeningen " bevilget et tilskud på $500 \mathrm{kr}$. til bøger. Indkøbet skete gennem "Sprogforeningen", og nu fik jeg biblioteket i god stand; der kom et udmærket udvalg af bøger, hvorfor også tilgangen af lånere blev større og større; disse nye bøger kom ved juletid 1921, og i denne vinter udlånte jeg hver middag gennemsnitlig 25 bøger. Alt dette foregik ganske uofficielt, lærerne vidste naturligvis besked; men alt foretog jeg for egen regning; en ganske enkelt af mine kolleger, M. M. Petersen, så vist i begyndelsen lidt skævt dertil, men da jeg aldrig med et ord havde anbefalet bornene at 
låne, og da bøgerne nationalt set var uangribelige, kunne han jo ikke indvende noget. Senere blev han øjensynligt også mere fortrolig med sagen, $i$ hvert fald kom hans egne børn også sommetider og bad om en bog. Ved begyndelsen af vinteren $1922-23$ blev det mig igen vanskeligt med de forhåndenværende bøger at tilfredsstille læselysten; mange havde læst rub og stub; ^Sprogforeningen " var da så imødekommende igen at yde biblioteket et tilskud på $500 \mathrm{kr}$., således at jeg selv kunne købe hos byens boghandlere, hvad jeg ønskede. Derved kunne jeg på een gang købe alle de børnebøger, som var af interesse, og som jeg ikke allerede havde, og blev således stillet, at jeg kunne købe alle nye børnebøger, efterhånden som de kom. Dette havde flere af drengene åbenbart lagt mærke til, thi så snart der i boghandlerens vindue var udstillet en ny bog, kunne jeg være sikker på, at der kom en og meldte: $\gg$ Hr. Torp! Der står en ny bog i Becks vindue, skal jeg ikke gå op og hente den? "Det fik han som regel lov til, og jeg behøver aldrig selv at føre kontrol med de nye bøgers fremkomst. Interessant er det under udlånet at høre børnenes indbyrdes samtale på tysk om bøgerne. Forleden dag (den 16. maj 1923) stod to små piger, der $i$ dette forâr begyndte at låne bøger, og skulle "have en bibliotek", som børnene siger; jeg stod ubemærket bag døren og hørte da den ene sige til den anden: "Sollst du auch ein dünisches Buch haben? — - Ja, natürlich, ich lese jeden Tag ein dänisches Buch « — gerne dünisch lesen, und das tut mein Vater auch ". Samtaler af lignende art har jeg hørt mange af. Jeg behøver vist heller ikke længere at være så forsigtig med bøgerne, som jeg er; bøger med Danebrog uden på, som jeg førhen nødig udlånte, tager børnene nu uden i ringeste måde at reagere. Forresten har skolen på nationale festdage lige fra først af hejst Danebrog, det er også sket på skoledage, og jeg har ikke bemærket noget $i$ den anledning hos børnene, over hvis hoved flaget vajede. I samme forbindelse kan nævnes, at børnene $i$ flere klasser allerede $\mathrm{i}$ første skoleår kom og bad om at måtte lære en dansk sang, og efterhånden han enkelte klasser lært ikke så få, som børnene altid er ivrige efter at få lov til at synge i timerne. I foråret 1922 foretog skolen en formiddag en tur ud til luftskibshallen, for at børnene skulle bese den, inden nedbrydningen begyndte; da vi marcherede hjem 
ad landevejen, sang børnene forskellige tyske sange, men midt under det hele begyndte de pludselig - uden at jeg naturligvis havde fremskyndet det - at synge en dansk sang, idet de med strålende øjne så tilbage på mig, der gik bag den pågældende klasse sammen med et par kolleger; det ikke mindst bemærkelsesværdige var, at ingen af de tyske lærere følte sig stødt, men tværtimod smilende hørte til.

Som før nævnt var jeg som eneste danske lærer, særlig $\mathbf{i}$ den første tid, omgivet med megen interesse blandt børnene. Kom jeg på gaden forbi et barn, der gik sammen med forældrene, hørte jeg ofte, før jeg vel var forbi, barnet hviske med stor iver: „Das var der dänische Lehrer * o. lign.

Vor skole havde særlig $\mathrm{i}$ det første par år efter genforeningen besøg af mange fremmede skolefolk og skoleautoriteter, bl. hvilke jeg vil nævne lærer Knudsen i Slagelse, professor N. A. Larsen, departementschef Aagesen og undervisningsminister Appel og frue. Alle disse besøg interesserede øjensynligt børnene, særlig ministeren og hans frue havde de store børn i 8 . kl. været meget optaget af; i denne klasse havde ministeren hørt $i$ dansk om familien Heiberg; børnene talte livligt, og ministeren var godt tilfreds. Et par dage efter blev jeg kaldt ned på amtshuset og fik efter ordre af ministeren af grev Schack på amtsskoledirektionens vegne overrakt en større boggave til minde om besøget; en lignende erindring fik overlærer Hansen.

Den 24. maj 1922 havde skolen besøg af kongen. Først på formiddagen skulle der bl. a. aflægges besøg $i$ den danske skole, hvorfra kongen med følge ville komme hen til os, efter planen ville det blive mellem 11 og 12 ; i denne time havde jeg skolens 8. kl., og jeg var naturligvis spændt på, hvordan besøget ville forløbe. Da timen begyndte, var børnene tydeligt præget af en vis forventningsstemning, om end enkelte måske ønskede i nogen grad at lade mere ligegyldige, end de $i$ virkeligheden var; megen opmærksomhed var der $i$ hvert fald den dag ikke ved undervisningen, og det varede ikke længe, inden en spurgte, om jeg ikke ville læse en historie $i$ dagens anledning, indtil kongen kom. Jeg læste, men jo mere tiden nærmede sig mod 12 , jo mere spredtes atter opmærksomheden. Hvad skal vi fortælle, når kongen kommer herind? " "Det ved jeg ikke, det bestemmer jeg ikke; måske 
noget om Holberg! " "Hr. Torp, "lyder det fra en anden, »hvornår er Holberg født? " "Det skal I slet ikke bryde jer om, det er der ingen, der spørger om! " Ja, men i hvad århundrede? " — Resten af tiden går med samtale mellem klassen og mig; tankerne kredser om kongens komme, der alligevel efterhånden tydeligt optager alle. " Er dronningen med? " spørger en pige. "Nej, dronningen er i København ". Skuffelsesudbrud fra pigerne. "Vi havde dog glædet os til at se en dronning! Kommer så nogen af prinserne? " „Ja, måske; det ved jeg ikke; men nu, når I hører de fremmede folk komme nede $\mathrm{i}$ gården, kan I så lade være med at løbe til vinduet «. Ja, det skulle de nok. Et øjeblik efter kommer der nogen på gangen; spændt forventning, som imidlertid udløses under latter, da døren går op, og den, der kommer ind, viser sig at være en lille dreng, som skal sige fra overlæreren, at klassen må blive efter kl. 12, indtil kongen kommer. Kl. er nu noget over sædvanlig ringetid, jeg er spændt på, hvordan børnene vil optage denne lille frihedsberøvelse. Først da der er gået noget tid, siger en, på en spørgende måde: "Jeg skal hjem og spise, hr. Torp, vi spiser altid kl. 12 «. Det samme siger under smålatter nogle andre. "Ja, jeg er skam også ved at blive sulten", siger jeg. \Nu må kongen da vist også snart komme «, siger en dreng, "må jeg lige løbe ud i Richtsensgade og se ad? * Ja, løb så hurtigt! « Snart var han her igen, men meldte, at der var ikke noget at se. Nogle minutter efter hørtes imidlertid op ad trappen lyden af mange menneskers komme; nu er det umiskendeligt, kongen kommer; børnene sidder stive af forventning; i dette øjeblik tænkes der sikkert ikke meget på dansk og tysk; men kun på dette: her kommer en konge, der vil høre os. Døren går op, hurtigt træder kongen ind; idet børnene springer op og står stive som støtter, svinger kongen sin marinehue, idet han råber noget ud over klassen, som jeg ikke rigtig opfattede. Da kongen er kommet op gennem rækkerne, giver han mig hånden, idet han siger på tysk: "Na, was machen Sie nun? " Han troede altså, at jeg var tysker; jeg svarede imidlertid: »Vi har dansk, Deres Majestæt! « \a, Deres Majestæt! det er den danske lærer, « sagde amtsskolekonsulenten, som stod i nærheden blandt kongens følge. "Nå, har De også sådan en her;" var svaret. På spørgsmålet, om kongen onskede at høre tysk eller dansk, ytrede kongen lyst til tysk, hvorefter overlæreren talte med bør- 
nene om et emne fra den tyske litteratur. Det kunne imidlertid nok knibe noget at holde klassens opmærksomhed fast, mens kongen og de mange folk var til stede; særlig grev Schack øvede stor tiltrækning i sin strålende amtmandsuniform. Kongen var øjensynlig i særdeles godt humør, han anbragte sig, let henkastet på et bord, der stod foran skolebordene, med benene strakt langt ud ad gulvet. Jæunlig tog han del i samtalen med børnene, stillede stikspørgsmål o. lign., og brugte over for børn såvel som overlæreren hele tiden det tyske sprog, hvilket ojensynligt gjorde et godt indtryk på alle; det var heldigt, ikke mindst af hensyn til de tyske byrådsmedlemmer, som, så vidt jeg ved, alle var mødt op sammen med de danske; kun de to socialdemokrater var der ikke. Jeg bemærkede af de danske, bagermester Thorvald Petersen, maskinbygger Rasmussen og bankdirektor Andresen; af de tyske bl. a. bygmester Julius Hansen og direktør Neven. Da amtsskolekonsulenten til sidst spurgte, om kongen også onskede at høre noget dansk, svarede denne: "Nej, det behøves ikke; du kan jo nok dansk! " sagde han henvendt til en dreng. Ja, det kunne drengen jo nok. Overlæreren holdt nu på tysk en kort takketale til kongen, der svarede meget venligt, ligeledes på tysk og forlod klassen, som -- det må bemærkes - var pyntet med blomster på katederet, ligesom der havde været stillet lænestole frem. Da kongen sammen med sit følge herefter gik over skolepladsen, kom han forbi 7. dr. klasse, hvis vinduer stod åbne. Lærer Gläser havde, for at drengene ikke skulle storme hen til vinduet, kommanderet dem til at sidde rette på pladserne og med hænderne foran sig på bordene. De sad så stive som støtter, og klassen med den strenge larer foran gjorde et noget "prøjsisk " indtryk. "Hvad er det for nogle drenge, hvorfor sidder de sådan? "spurgte kongen. "Det er fordi, de skal sidde ordentligt, når Deres Majestæt kommer forbi «, svarer amtsskolekonsulenten. Kongen træder hen til vinduerne og kommanderer med høj røst: »Augen — links «! og øjeblikkelig ser naturligvis alle hen til kongen, hvorefter tavsheden afsløres med stor munterhed. "Her vil jeg ind ", siger kongen, og snart er han med hele følget $i$ klassen, som han på en fornøjelig måde eksaminerer om Alexander den Store. Kongens måde at optræde på bevirkede, at besøgets hele forløb var meget heldigt; særligt havde det naturligvis gjort et godt indtryk, at kongen havde 
talt tysk. Dette fik jeg straks et tydeligt bevis på. Da kongen kom fra gymnastiksalen, hvor han havde set forskellige folkedanse, stod jeg $i$ en klasse sammen med nogle kolleger og så ud af vinduet; talen drejede sig om besøget, og en af dem (lærer Lammers - sydslesviger - sikker tysk) udbrød da på tysk: "Hvor er det smukt, at landets konge også besøger vor skole, når han er i byen, og bruger vort sprog ". Denne udtalelse blev modtaget velvilligt af de øvrige tyske lærere og suppleret med andre lignende. Man kan vist nok således tillægge et sådant kongebesøg nogen betydning - desværre bragte byens konservative avis ( Tønder Amts Tidende«) straks efter en dum artikel, hvori på en uheldig måde omtaltes, at de tyske byrådsmedlemmer gav møde ved modtagelsen på Torvet og fulgte kongen under besøget. Ved frokosten på Schackenborg deltog bl. a. overlærer Hansen fra vor skole.

\section{Dagbog 1923.}

27. april. Bededag har jeg tilbragt i Flensborg for at gøre mig nærmere bekendt med det danske skolevæsen. Først på den nye realskole, som nu, skønt ikke færdig, var taget i brug. De børn, jeg hørte, beherskede dansk fuldkomment og gjorde et godt indtryk; jeg hørte på lærer Billums undervisning og talte med dr. Andreas Hansen. Også på skolepladsen talte børnene dansk. Om eftermiddagen var jeg på den såkaldte »Tivoliskole*. Her var de børn, som sidst var kommen fra de tyske skoler, hvor alle skal gå $i$ de fire første år. Disse børns standpunkt $i$ dansk var ikke så godt; de forstod alle dansk, men ikke mange kunne tale det ordentligt, enkelte kunne egentlig slet ikke, mange var meget forsømte. Jeg hørte på undervisningen hos lærer Ejnar Olesen og lærer Kirchhoff. På lærerværelset havde jeg en lang samtale med skolens leder, inspektør Petersen. Han, der viste sig ikke at være "Flensborg-mand", udtalte bl. a., at han ikke ville virke i Flensborg, hvis han ikke havde den faste overbevisning, at dansk kultur ligger slesvigerne nærmere end tysk, og at det ville være det bedste at opdrage dem heri, da den tyske kultur for de fleste var uimodtagelig og førte ud $\mathrm{i}$ åndelig fattigdom, ja i åndløshed (Angel) - Det kan ikke nægtes, at der ligesom mærkes et »dansk pust i Flensborg nu; man kan 
ikke være her længe, inden man rent praktisk ser, at der er et dansk spørgsmål her. (Børn med danske skolehuer, danske inskriptioner i vinduer og på hoteller, "Flensborghus", "Ansgar", Det danske Konsulat, skoler, Flensborg Avis Central o.s. v.), men hvor meget er valuta? Det er det pinlige spørgsmål, selv for rettænkende Flensborg-folk.

29. april. I dag så jeg $i$ alléen en tysktalende dreng med en dansk matroshue med navnet "Søridderen" på hovedet.

31. maj. Kongen besøgte i dag grænseegnene. Ved Pebersmark gik han over grænsen og talte venligt til nogle på tysk side forsamlede børn, der stod om en mand, der antagelig var deres lærer; pludselig vendte han på en uforskammet måde kongen ryggen og gik væk med børnene; nogle siger, idet de sang SlesvigHolsten visen; dette sidste har jeg dog ikke fået bekræftet. I Tønder fik kongen en hjertelig modtagelse, som fandt sted foran amtshuset; her var de fleste byrådsmedlemmer og garnisonens officerer. Ledsaget af grev Schack og amtsskolekonsulent Svendsen blev museet, som nu var færdigt, beset. Senere på dagen blev der aflagt besøg i forskellige skoler, bl. a. i Bredebro. Her havde børnene skrevet på tavlen: "Vi hilser Deres Majestæt velkommen". Kongen greb da et stykke kridt og skrev nedenunder:: "Mange tak! Christian R. "

4. juni. På skyttefestens anden dag kom nogle danske officerer i uniform ind på "Svejtserhalle«, hvor brødrene, der for langt den største parts vedkommende er tyskere, var forsamlede. Da det var den 2. dag, kunne man jo nu egentlig have ventet ubehageligheder; men det gik ganske anderledes. Skytterne modtog officererne med åbne arme, ja, havde nær omfavnet dem; de blev straks forestillet korpsets major (snedkermester Popp), hvorefter de blev indbudt til at tage del i selskabet, hvilket tilbud officererne var så fornuftige at modtage; og de blev der i længere tid. Denne lille begivenhed sammen med flere lignende er for mig et bevis på, at der hos det tysksindede borgerskab er en trang til at komme de danske autoriteter venligt i møde. Jeg kommer her til at tænke på, at min værtinde, som er tysk, om eftermiddagen efter det sidste kongebesøg kom ud i gården til mig og under samtalen sagde, at hun hele dagen havde været til kaffegilde ovre hos en af 
genboerne, "for", sagde hun, "det er jo kongebesøg i dag, og man er da alligevel helt højtidelig, så man kan dog ikke bestille noget ".

9. juni. I dag kom en flok af de store piger fra 8 . kl. hen til mig $i$ frikvarteret og sagde: "Må vi ikke lære en dansk sang $i$ denne time. Der er ingen mening $i$, at vi ikke lærer nogle danske sange; nu har vi haft dansk $i$ tre år og kan ingen". — Tyske børn fra den udskregne tyske by, Tønder!!

10. juni. I pinsen var jeg på cykleudflugt i Sydslesvig. En aften spiste jeg i Rødekro i Lille Danevirke. Kromanden og hans kone, der var tysktalende og tysksindede, var intelligente og tiltalende folk. Da jeg betalte, sagde manden: $\AA \AA$, ja, det er snart ligegyldigt med disse marksedler; vi får jo så mange, at vi kan stable dem; men nu får vi også snart kroner — heldigvis". »Får De kroner; hvilke kroner? " "Danske kroner, naturligvis; for til efteråret, når Tyskland bryder sammen, bliver vi danske". "Nej, det tror jeg ikke, befolkningen her har jo aldrig ønsket at blive dansk, og Danmark ønsker ikke at få landet, når folkene ikke ønsker at komme til os ". Da smilede manden og sagde: "Der er slet ingen, der spørger Danmark; nej, Frankrig skal have erstatning af Tyskland, og når dette land efter sønderlemmelsen ikke kan betale, siger Frankrig til Danmark om at tage hele Slesvig mod at betale en stor sum til den franske stat. - Det er Danmark, som jo er Frankrigs vasal, nødt til at gå ind på ". Jeg søgte at gøre ham forklarligt, at Danmark aldeles ikke er afhængig af Frankrig og stillede ham det spørgsmål, om han troede, at Sydslesvigs befolkning ville være danske. "Hvad, skal vi være danske! " sagde en ældre dame, som nu kom til. \Nej, jeg siger: Tror De, at folk her vil være danske? " "Være danske? " sagde hun, og der kom et næsten hadefuldt udtryk $i$ hendes ellers venlige øjne, "nej, det kan De tro, vi ikke vil; det har vore forfædre jo kæmpet to gange for ikke at være". "Der kan De høre", sagde jeg vendt mod manden, "tror De, at bønderne her vil være danske? " "Ja", sagde han, "tiderne kan blive så svære her i Tyskland, at vi må ønske os til Danmark. For brødets skyld." "Men så når Tyskland igen kommer på fode? « — »Ja, så vil vi på hænder og fødder atter søge til Tyskland ". - "Ja", svarede jeg, "det kan De tro, vi nok 
ved hjemme i Danmark, derfor tror jeg også, at vi ikke alene vil spørge Dem hernede, men også hele det danske folk, før vi eventuelt vil modtage Sydslesvig, og da tror jeg ikke, at der bliver flertal derfor; thi det vil blive klart, at De kommer af sult «.

Det er mærkeligt i denne tid overalt i Mellem- og Sydslesvig, både blandt danske og tyske, at høre denne sikre forvisning om at blive danske i nærmeste fremtid. Skulle 'Tyskland opløses, stâr Danmark således måske over for skæbnesvangre afgørelser. Men hvem tænker på, at der rører sig så skæbnesvangre ting lige uden for vor dør". - Ingen! Danmark sover sin tornerosesøvn.

30. juli. Jeg kom i dag hjem fra en ferierejse til Tyskland og Italien og blev straks glad ved at se posten, thi blandt den var der en hel del kort fra mine elever i 8. kl., som sammen med nogle lærere havde foretaget en længere udflugt til Harzen. Kortene var skrevet på dansk.

20. august. Skolens to $1 . \mathrm{kl}$. havde i eftermiddag en lille udflugt til Sønder Markhus "(Süder Feldhaus) «. Lærerne, deres fruer og en hel del forældre var med. Af et par store poser blev der uddelt forskellige smågaver, hvoriblandt var en stor del billedbøger med dansk tekst. En pige gik hele dagen rundt med en "Billedbog for artige Børn" — Vore tyskere synes selv at være nogle "artige born".

Senere på eftermiddagen var landstingsmand $\mathrm{H}$. Jefsen Christensen på amtsskolekonsulentens kontor, han fortalte, at han på den fornylig afsluttede interparlamentarikerkongres i København var kommen til at gå lige bag Johs. Tiedje ("Tiedje-linjen" — ansat $i$ indenrigsministeriet $i$ Berlin) og folketingsmand, pastor Schmidt. Tiedje ytrede da, at man i Berlin var klar over, at behandlingen af tyskerne i Nordslesvig var upåklagelig, og at man, særlig i Tønder amt, tog alt hensyn til berettigede ønsker fra den tyske befolkning. $\$$ Ja, det gør amtsskoledirektionen i Tønder nu ikke", svarede pastor Schmidt; "ved en embedsbesættelse i Rends forelå der en adresse fra 95 pct. af beboerne med anmodning om at få den af skolekommissionen som nr. 1 indstillede lærer kaldet; men trods dette ansatte direktionen dog ikke ham, men nr. 2." Jefsen Christensen trådte nu til: „Ja, undskyld, mine herrer, at jeg 
blander mig i Deres samtale, som jeg ikke kan undgå at høre; da jeg er medlem af skoledirektionen, er jeg interesseret $\mathbf{i}$ den omtalte sag, som er bedst at få klaret straks. Vil De derfor ikke, pastor Schmidt, sige, hvilken lærer De tænker på? «. Denne blev åbenbart herved noget ubehagelig berørt, men nævnede endelig, at han havde tænkt på lærer Andersen. "Hertil er at sige ", svarede Jefsen Christensen, »at lærer Andersen aldeles ikke var kvalificeret til stillingen som førstelærer i Rends, hvad han selv har indrømmet; men De glemmer at fortælle, pastor Schmidt, at det her drejer sig om en embedsbesættelse ved den danske skoleafdeling og ikke ved den tyske, så for så vidt kommer det Dem slet ikke ved; og De ved jo godt, at De ikke kan nævne et eksempel på, at der ikke er blevet taget hensyn til det tyske mindretals berettigede ønsker". Dette indrømmede pastor Schmidt. Senere sagde Jefsen Christensen til Johannes Tiedje: "Hvordan kan De, Tiedje, som dog kender forholdene her, hævde retfærdigheden af Tiedje-linjen som grænse; De ved jo dog, at grænsen af praktiske grunde måtte blive, som den blev". Hertil svarede Tiedje, at han ikke selv mente noget alvorligt med denne linje, som var opstillet for at give de mere moderate tyskere et standpunkt, ellers ville blot alle, der interesserede sig for Slesvig, kaste sig i armene på Kongeå-politikerne (Schmalfeldt: "Die Königsau "), hvad han ikke ønskede; det var altså af rent taktiske grunde, han havde opstillet sin grænselinie. Hertil bemærkede Jefsen Christensen, at han måtte være klar over, at dette standpunkt var en leg med ilden, og at hans tidligere venner i Nordslesvig måtte stille sig uforstående over for ham nu. Som et bevis på de fortvivlede forhold i Tyskland fortalte Tiedje, at han umuligt kunne være kommen med til denne konference, hvis han ikke havde rejsen gratis, og at han $i$ fire år ikke havde kunnet besøge sine forældres grave i Nordslesvig. Amtsskolekonsulenten fortalte, at Tiedjes far havde været ivrig dansksindet; da han som dansk officer havde stået på Danevirke i 1864, havde han strakt armen og sablen ud mod syd og sagt: "Lad dem komme de satans tyskere, så skal de få bank ".

22. august. I dag blev Rudbøl skole indviet, den nye skole skal være dansk afdeling og den gamle bygning, som er smukt istandsat, tysk. Hidtil har der ingen dansk afdeling været. Ved indvielsen talte først skolekommissionens formand, gårdejer Lorenz Niel- 
sen, derefter grev Schack, Jefsen Christensen og amtsskolekonsulent Svendsen, der gjorde forældrene opmærksomme pâ, at de nu efter indvielsen ved henvendelse til den danske - henholdsvis den tyske lærer måtte melde deres børn til dansk eller tysk undervisning. Konsulenten betonede stærkt, at man ikke ønskede på nogen måde at lægge tryk på nogen, enhver skulle handle i fuld frihed og eget ansvar. Efter indvielsen rejser de rige tyske gårdejeres fruer sig, som efter aftale, og gik demonstrativt i flok og følge, idet de kastede deres udfordrende blikke på de noget tilbageholdende danske småfolks hustruer, der øjensynligt ved et moralsk tryk nu skulle bruges til også at melde deres børn hos den tyske lærer. Taktikken slog imidlertid fejl. Amtsskolekonsulenten havde snart, fortrolig som han indtil mindste enkeltheder er med forholdene, gennemskuet planen og hindrede derfor de tyske fruer $\mathrm{i}$ al blive stående $i$ anmeldelsesrummet og udøve kontrol over for de danske, ved at sige: "När damerne er færdige, vil De måske være så venlige at gå denne vej rundt at bese den nye skolebygning, så at der kan blive plads for de næste". Så måtte de bort, og småfolkene kom alle som een og meldte sig med deres børn hos den danske lærer. Resultatet blev, at 12 familier med 18 børn meldte sig til den tyske afdeling, mens 14 familier med 27 børn meldte sig til den danske. Amtsskolekonsulenten fortalte, at det var rørende at se danskernes glæde over dette resultat.

24. august. Et forlydende vil vide, at de tre tyske blade i Nordslesvig på grund af økonomiske vanskeligheder skal trykkes på et sted, og at bl. a. redaktørerne Bødewadt og Hamann (begge uduelige!) ved »Neue Tondernsche Zeitung " snarest vil få deres afsked. Der er flere ting, der tyder på, at det står svagt til i de tyske rækker; de tyske vandrelærere (Dehn og Matzen) har begge meldt sig med anmodning om at komme i dansk skoletjeneste ved en af de tyske afdelinger. Hamann, der er lærer, har forespurgt om noget lignende, og . . . lærerinde (ved privat skole) frk. X trygler stadig derom, og laser på Svendsens henstilling flittig dansk og går til provst Christensens gudstjenester. Hun er vist i stand til højtideligt at afsværge sig al tyskhed, hvis det var nødvendigt for at få en stilling. - De mørke tilstande i Tyskland er naturligvis $\mathrm{i}$ høj grad årsagen til disse forhold. 
27. august. I dag var der kommen en ny dreng i 4. kl., som på grund af sit smukke ansigtsudtryk og karakteristiske ydre straks tildrog sig min opmærksomhed. "Han kan slet ikke dansk «, sagde de andre. Det viste sig at være rigtigt, og jeg måtte da stille ham de nødvendige spørgsmål på tysk. »Hvad hedder du? « spurgte jeg. "Diedrich Bøhme". "Hvad er din far, og hvor bor I ". " Mein Vater war Landrath, er ist gestorben «, var drengens grådkvalte svar, og târerne trillede ned ad hans kinder. Det var altså en søn af den tidligere så strenge og frygtede landråd Bøhme i Tønder, som efter genforeningen blev landråd i Syd-Tønder kreds, og der under en køretur på et af marskdigerne forulykkede. Det var vemodigt at se den 9 -års drengs sorg over at blive mindet om faderen.

12. september. I eftermiddags var jeg på cykletur til Aventoft; jeg fik som sædvanlig en længere passiar med den tyske tolder; han - en tiltalende midaldrende mand - så meget sort på forholdene. »Vi kan her ikke forstå, hvorfor et pund smør, der i går kostede 12 mill. mark, i dag koster 24 millioner". Da jeg ville gå, sagde han: "Wenn Sie Kronen verkaufen wollen, dann denken Sie ja an uns; die Bauern geben uns keine Dewisen. "Jeg havde nu ikke brug for mark, men lod dog forstå, at jeg gerne ville have 1 kr. omvekslet, så jeg kunne købe en kop kaffe henne i kroen. "Ja, das war sehr freundlich von Ihnen, werden Sie einen Augenblick warten, dann werde ich mein Geld holen". Og han — en tysk embedsmand - forlader kontoret med papirer og alt - og løber hen ad vejen til sit hjem, hvorfra han snart kommer med hånden fuld af penge; jeg fik 15 millioner og tolderen 1 krone; han var lykkelig: „Dass ist meine zweite Krone", sagde han. Hver gang jeg skulle købe mark, ville han bede mig købe hos sig; var han ikke hjemme, kunne jeg gå til hans kone. - Tanken ledes uvilkårligt hen på de stive prøjsiske embedsmænd for krigen. Der er forskel, så det forslâr noget.

I Aventoft besøgte jeg fisker Theodor Andersen, formand for den stedlige slesvigske forening. Konen havde lige (d. 9. ds.) været til det store danske årsmøde $\mathrm{i}$ Flensborg og var meget begejstret derfor. I den slesvigske forening i Aventoft var der nu 37 medlemmer, og der ventedes flere til vinter. Tyskerne her nærer ikke noget venligt sindelag over for medlemmerne; $i$ virkeligheden, mente konen, ønsker begge parter, at Tyskland skal gå til grunde, 
for at i hvert fald den dansktalende del af Slesvig kan komme til Danmark. "Jeg tror ikke, at Danmark vil gere noget skridt dertil; hvorledes vil man gribe sagen an ". "Ved henvendelse til Folkenes Forbund «, lød svaret. På mit spørgsmål angående sprogforholdene udtalte begge, at alle $i$ byen med undtagelse af præst og lærer havde dansk hjemmesprog, og at ingen, på de nævnte undtagelser nær, kunne tale rent tysk. "Børnene får det aldeles ikke lært $\mathbf{i}$ skolen; læreren anser dette for umuligt; de to første skoleår er tabte for de fleste børn, som intet forstår ". Læreren er fra Als, hans kone ligeledes, begge taler dansk med befolkningen og er meget fornuftige. Andenlæreren er fra Holsten, til ham er forholdet ikke så godt. Befolkningens tysksindede del føler sig, trods sindelaget, i tydeligt modsætningsforhold til alle egentlige tyskere. "Hvad skal disse tyskere her! " udtaler de ofte om grænsegendarmer og andre embedsmænd. Da der kom børn på ferieophold i Danmark, og nogle embedsmændsbørn kom med, sagde mange af de tysksindede: "Det er der ingen mening $i$, hvad skal de tyskeres børn med til Danmark for".

Konen havde for nogen tid siden været i Nibøl og her truffet sammen med en stor frisisk marskbonde, der under afstemningen havde været stærkt tysk. Nu var han bleven dansk og udtalte sammen med kromanden ønsket om, at Tyskland måtte bryde sammen, "så kommer de danske soldater og besætter landet her; Danmark beholder det da og bringer alt på fode«. Hertil havde fisker Andersens kone sagt: »Nej, det gør Danmark ikke, dertil er det alt for frisindet et land «. Det kunne friseren ikke forstå. »Vi, har dog før været danske«.

16. september. På cykletur til Klangsbøl for at bese dæmningsarbejdet til Sild, undervejs på besøg hos Martin Andresen i Verlath kro. (Han har i sin tid stemt tysk). Da den internationale kommission var der, havde Claudel udtalt sin forundring over, at han ikke ville stemme for Danmark. »Det kan jeg da ikke med respekt for mig selv, jeg har altid været tysk i den gode tid og kan nu ikke for fordels skyld kalde mig dansk". Sådan er denne mands standpunkt; han som mange tyskere her på egnen ville ikke stemme dansk, men ønskede, som han så ofte har sagt mig, at Danmark skulle have taget dem. Inden længe er vi så inde i den 
sædvanlige samtale om 'Tysklands elendighed. "Hvad skal der blive af os; nu fâr vi ved siden af alt det andet eventyrlige store skatter; vi har ingen lyst til nogle ting mere". Jeg: "Slesvig og Holsten er frugtbare lande, det er meningsløst, at de skal lide nød, fordi Prøjsen har et mellemværende med Frankrig. De må se at komme løs «. "Ja, det er lige det, jeg har tænkt på længe; vi har jo ikke noget med Prøjsen at gøre, da vi gjorde oprør i 1864 var det ikke for at komme under det land, men for at vinde selvstændighed. Vi har kun haft ulykke af Prøjsen, som altid har sendt os fremmede embedsmænd, som ikke forstod os, og som kom med deres "Kriegervereine" og alt dette blot for at trykke os. Men hvad skal vi, vil Danmark have os? « Jeg udtalte min absolutte tvivl om, at Danmark ville have mere end den dansktalende del, men henviste til Islands stilling og opkastede tanken om, at forholdene måske kunne ordnes på lignende måde her. Andresen, der var synlig nedtrykt over de øjeblikkelige tilstande, oplivedes ved denne lanke, som han gav sin tilslutning.

19. september. I dag var jeg i Flensborg; Tyskland er nu millionernes og milliardernes land; rejsen Tønder-Flensborg tur-retur kostede 150 millioner mark, en middag 40 millioner og for at blive barberet 8 millioner, allerede i morgen er disse i følge erfaringer imidlertid overfløjet og endnu større.

\section{4.}

17. oktober. I omtrent et år har jeg ikke fâet noget nedskrevet, skønt det har været en tid rig på begivenheder og udvikling — kun travlhed har hindret mig. Jeg håber, at jeg herefter mere regelmæssigt skal få lejlighed til at nedskrive mine oplevelser. Diskusionen om det dansk-tyske mindretalsspørgsmål har nu antaget en mere praktisk form, idet der i disse dage føres en forhandling i København mellem skolefolk fra begge sider af grænsen. Officielt har tyskerne i deres grænsepresse proklameret kravet om kulIurel autonomi; for at høre lidt nærmere om motiverne derfor, foretog jeg for en uges tid siden en rejse i Sydslesvig og talte med ledende tyskere der. I Slesvig opsøgte jeg som så ofte før tidligere seminarieoverlærer Tränckner (nu Studienrat). Indledende pegede han på et gammelt fotografi af sin far i dansk officersuniform, 
faderen havde varet loyal og deltaget $i$ kampene ved Danevirke $i$ 1864; Frederik d. 7.'s navnetræk fra distinktionerne af hans officersuniform var sat fast på rammen. Vi drøftede i en læengere samtale denne og den følgende dag mindretalsspørgsmålet; jeg hævdede, at kulturel autonomi med et nationalt kataster ville være en ufrisindet ordning, da mange, der $i$ virkeligheden folte sig hørende til mindretallet, af økonomiske grunde ikke vover at melde sig, hvorfor mindretallene synes mindre, end de i virkeligheden er. Heroverfor havdede Tränckner $i$ en lang udvikling, at spørgsmålet for ham ikke i første linie var, om mange eller få kom med, men at ordningen blot blev sâledes, at staten ikke kunne blande sig ind $\mathrm{i}$ mindretallets anliggender. Tränckner udtalte senere, at han sä godt forstod "Flensborg Avis", og at han, hvis han var dansk, sikkert ville være blevet »Flensborgmand «. I Rensborg besøgte jeg pastor Tonnesen, der i mindretalsspørgsmålet viste sig at stå på sammen standpunkt som Tränckner og forsvarede det $i$ hovedsagen med samme argumenter. Også for ham kom det ikke an på størrelsen af det antal, der melder sig til det nationale kataster, men han udtalte, at alle de lyssky elementer, som ville stå sig godt med begge parter, netop ikke skulle have lejlighed til at betragtes som mindretal. Jeg gjorde pastor Tonnesen opmærksom på de danske privatskoleforhold og pâviste, at tyskerne her havde betingelser for at danne skoler, på hvilke statens indflydelse ikke kan gøres gældende. Pastor Tonnesen syntes at ville indrømme det, idet han ikke støttede pastor Schmidt's krav on større tilskud til tyske privatskoler end til danske. Han talte smukt dansk, klogt og tiltalende, og dog var jeg forbavset over at mærke, hvorledes han troede på enkelte af de tyske forvrængninger om forholdene i Nordslesvig, bl. a. at lærerne ved de tyske skoler overvejende er dansksindede.

Under samtalen kom hans frue ind og hilste, hun havde iøvrigt tydeligt nok ikke noget egentligt ærinde, hvilket hun ikke kunne skjule; hun gik hen og tog i en dør, der slet ikke kunne lukkes op, og sagde da egentlig lige ud: "Ja, jeg hørte, der blev talt dansk, og så måtte jeg herind «. Pastor Tonnesen karakteriserede danskerne ved, at der var sådan en stil, skonhed og smuk harmoni over alt, hvad de foretager sig, selv de simpleste ting. "Jeg kommer til marked i Haderslev og må gribe mig til hovedet og tænke: "Hvad er 
dog dette, som giver selv sådan en hverdagsagtig ting sin skønhed «. Vi tyskere derimod er ikke kommen rigtig i form, og vi falder folk på nerverne". Ved middagsbordet bad han først en bøn på tysk, og efter spisningen bad han på dansk, dette sprog. som i det hele bruges meget til daglig mellem ægtefællerne, mens derimod børnene tiltaltes på tysk, ihvorvel de forstod dansk.

I Sydslesvig var forholdene anderledes end sidste år, da fantastiske planer om en ny sydligere grænse opfyldte sindene.

17. oktober. Det var, som om man efter rentemarkens indførelse var vågnet af en drøm til den nøgterne virkelighed. Mange tilløbere til de danske (tyskskrevne) aviser og foreninger er faldet fra, men der synes at være en fast kerne tilbage, som mener at kunne holde stillingen ved valgene og efterhånden vinde fremgang. Jeg overværede en sammenkomst $i$ »Slesvighus «. Her var mødt ca. 100 personer - gamle og unge; disse første talte gennemgående tysk og forstod kun delvis dansk; de unge, hvoraf flere havde været i Danmark, havde mere kendskab dertil og underholdt sig delvist med hverandre på dansk. Der blev kun sunget danske sange og mest talt dansk af foredragsholderen (en lysbil. ledserie fra Danmark).

En aften besøgte jeg en af de mest kendte danske familier, tømrer Ilpers (Hafengang 6); Ilper er fra Eckernførde og af slesvigsk slægt; han taler nogenlunde godt dansk og gjorde et sympatisk indtryk. Hans hustru er født $i$ byen Slesvig og taler udmærket dansk (familie i Danmark, flere ophold her) ... I det hele taget mangler der i Slesvig by blandt de danske ledere førsterangskræfter. Dertil kommer, at »Slesvighus " ligesom de forskellige institutioner i Flensborg er altfor stort og kostbart at drive. Rammerne for det danske arbejde syd for grænsen synes $i$ så henseende at være noget vide.

22. oktober. Det var i dag overlærer Hansens fødselsdag; bør.nene havde pyntet klassen meget smukt; da jeg kl. 11 skulle have dansk der, havde en dreng skrevet følgende vers på dansk på den sorte tavle:

De svandt, de svandt de glade timer kun efterladende nogle minder, nu rinder sveden atter ned ad vore kinder. 


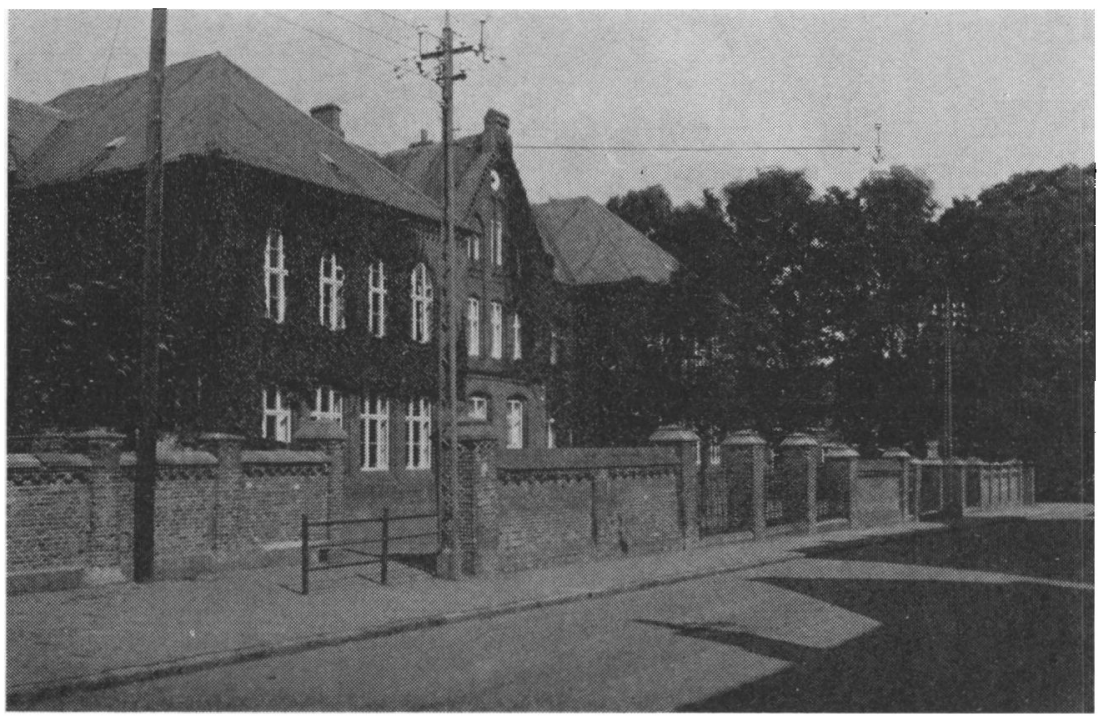

Richtsensgades skole

Og derefter: "Må vi fẩ en hislorie ". - Atter et bevis for, at der ikke trives nogen aversion blandt bornene mod det danske sprog. Lejlighedsvis blev jeg forresten i dag klar over, at de danske ugeblade, særlig Familie-Journalen i meget høj grad er trængt ind i disse børns hjem. Eleverne taler med stor interesse om bladenes indhold, uden at man mærker gnist af betænkelighed, fordi de er danske. Selv elever, der har noget svært ved dansk, hvor hussproget er absolut tysk - sydfra tilflyttede familier - , synes at betragte det som en selvfølge, at de læser disse blade, der således må siges at have en betydelig sproglig mission. Også på anden måde er jeg blevet opmærksom på dette forhold. Ved overlærerens fødselsdag, hvor skolens lærere var til stede, oplæstes et lykønskningsbrev fra lærer Gläser, der for tiden er på årskursus i dansk på Statens Lærerhøjskole. Hans brev var på en næsten udelukkende anerkendende måde fuldt af omtale af skolen og forholdene i København. I overgangstiden var han yderligtgående tysk, han demonstrerede mod de engelske soldaters indtog ved at stå på advokat Todsens trappe og se ud i luften med korslagte arme, mens tårerne løb ham 
ned ad kinderne. Nu er han meget optaget af danske forhold, hører i København forelæsninger i historie hos Aage Friis og arbejder på at få dansk studentereksamen. - Ved oplæsningen og efter denne drejede samtalen sig lange om forholdene i København, som om man alle dage havde levet under Danmark. Jeg fik et tydeligt indtryk af, hvorledes den del af opsigningen, der består $i$ at knytte tråde mellem disse folk og det gamle land, er $i$ fuld gang.

23. oktober. I Horupsgade kom jeg $\mathrm{i}$ dag forbi to drenge fra skolens øverste klasser; de legede og talte dansk sammen, den ene har i hvert fald ikke dansk hjemmesprog.

18. november. Lærerne i Højer, d. v. s. den danske førstelærer, Aage Nielsen, og den tyske førstelærer, Hans Olde Petersen, enes meget dårligt. Den første er noget stejl og rethaverisk, den anden snu og underfundig....; fra tid til anden har der været stridigheder mellem parterne. I skolekommissionen er der kun eet dansk medlem, købmand Knud, der på en meget ihærdig, men samtidig noget ilter måde varetager de danske interesser. Formanden er borgmester Johannsen, en svag mand, der lader sig drive frem af de yderligtgående tyskere, der er mere ivrige end kloge $i$ deres politik. I dag havde de tre tyske lærere, foruden den ovennævnte, tillige andenlærerne Sørensen og Brockmann, stævnet lærer Nielsen for retten $\mathrm{i}$ Tønder, fordi han skulle have sagt til vikaren $\mathrm{i}$ det danske andenlærerembede: "De skal ikke lade Dem tude ørerne fulde af løgn af de tyske lærere «. De tyske læreres sagfører var advokat Sievers, den danskes sagfører var Løve. På dommer Gjessings forespørgsel til.lærer Nielsen, om han havde brugt den nævnte ytring, svarede han nej, og da der ingen vidner var, trak de tyske lærere anklagen tilbage, og der kom ikke noget ud af det hele. Men den historie, så latterlig som den er, er karakteristisk for tilstanden i Højer i øjeblikket. Tyskerne kan ikke få ind $i$ hovedet, at de ikke stadig kan skalte og valte med danskerne, som de lyster. Da der for nylig var et andenlærerembede ledigt ved hver af de to skoleafdelinger, fik tyskerne i skolekommissionen naturligvis uden modstand fra dansk side lov til at bestemme, hvem de ville indstille til det tyske embede (Brockmann, tidligere i Tønder, nr. 1), men de ville også bestemme over, hvem der 
skulle indstilles til det danske embede uden at tage hensyn til det danske skolekommissionsmedlems ønsker; de indstillede tre, hvoraf den ene $i$ hvert fald var meget ringe kvalificeret, særlig i dansk .. Fra dansk side indgaves en særskilt indstilling med lærer Vetter fra Erritsø ved Fredericia som nr. 1, og han blev kaldet, hvilket naturligvis harmer tyskerne, der aldeles ikke synes at respektere folketingsmand, pastor Schmidt's ønske, at tyskerne ikke skal blande sig i danskernes skoleforhold og omvendt. De protesterer nu i harmfyldte vendinger i skrivelser til ministeriet, der formentlig vil give et skarpt og af visende svar.

20. november. Vi havde i eftermiddags lærermøde (konference) på skolen. Lærer Marinus Petersen holdt foredrag over emnet "Sind wir mit der Rechtschreibungsunterricht zufrieden?" Han besvarede det benægtende og omtalte som en af vanskelighederne det danske og dårlige tyske omgangssprog i byen, men nævnede også, at den danske undervisning på skolen havde en uheldig indflydelse på elevernes standpunkt $i$ tysk, ligesom det var vanskeligt i flere tilfælde at afholde børnene fra at bruge latinske bogstaver mellem de gotiske. Forholdet er jo det, at alle børnenes omgivelser uden for skolen bliver mere og mere danskprægede, overalt hvor de kommer, møder de det danske, i forretninger (skilte og betjening) i teater og i biografen $o$. l. steder. En stor indflydelse har de danske ugeblade, Familie-Journalen og Hjemmet, der nu kommer i de fleste hjem og ofte af børnene omtales med den største velvilje.

30. november. Skuespiller Texiere læste i aften H. C. Andersens eventyr på "Tønderhus «; der var kommen mange flere mennesker til stede, end salen kunne rumme, hvorfor seminarielærer Schrøder tog anledning til at udtale onsket om, at de fornylig fremkomne planer om at udvide "Tønderhus " snarest må blive virkeliggjort. Den store forsamling fulgte Texieres oplæsning med stor interesse og tydeligt nok med forståelse; så indlevet er man allerede nu i danske forhold og tilstande, at man forstår enhver lille hentydning. Da vi alle forlod salen, bemærkede jeg blandt tilhørerne en ung pige, som for et par år siden udgik fra den tyske skole, og som endnu har en broder der; jeg havde hidtil troet, at hun lagde vægt på at være tysk. Forresten har jeg også ofte set en 
datter af lærer $\mathrm{X}$ der, ligesom en del tysk ungdom kommer der gennem Tønder Boldklub; det er derfor meget beklageligt, at formanden for *Tønderhus «, laboratorieejer Busch, i sin beretning ved selskabets generalforsamling fornylig omtalte "Tønderhus " som danskhedens højborg; særlig når der foreligger muligheder for at få tyskerne til at indfinde sig, er det ikke klogt at omtale den slags.

3. december. Blandt de børn, der i dag var ved det danske bibliotek, var også en pige med en rund matroshue, hvorpå der stod navnet på et dansk krigsskib, og på siden var der en stor dansk kokarde. Pigen var ganske vist fra et dansksindet hjem ... men det er dog bemærkelsesværdigt, at pigen kan gå $\mathrm{i}$ den tyske skole med en sådan hue, uden at nogle reagerer derimod. Da jeg $i$ eftermiddags kom ind på posthuset sammen med lærerinderne frk. Krogh og H. Petersen, så jeg forresten der en anden lille pige, netop fra frk. Krogh's klasse, der også havde sådan en dansk hue på med navnet Niels Juel .

4. december. Det under 20. november omtalte lærermøde fortsattes i dag. Skønt vi endnu ikke var kommen til det punkt i forhandlingen, bemærkede lærer Lammers dog, at så snart børnene kom i 4. klasse, hvor danskundervisningen begynder, ser man, at deres tyske retskrivning bliver påvirket af den danske, de skriver f. eks. ofte $f$ for $v$. Til de mange klager over den tyske retskrivning: "So ist es schon seit 80 Jahren hier in Tondern gewesen, und so wird es auch in den nächsten 30 sein «. Der lød da et tilråb: "Dann ist es schlimmer". Jeg fik af forhandlingerne i dag det i og for sig glædelige indtryk, at undervisningen i tysk retskrivning foregår under stor vanskelighed. Lærer Petersen og fru Grandt udtalte, at efter deres erfaring stod det meget bedre til med børnenes retskrivning syd på end her.

12. december. I aften var på Tønderhus samlet repræsentanter for "Det konservative Folkeparti " (laboratorieejer Busch og landsretssagfører Løve), „Venstre" (seminarielærer Cl. Eskildsen og postmester Jørgensen) og Det radikale Venstre (entreprenør Dela og lærer Torp) til en forhandling angående byrådsvalget $i$ marts 1925 med det formål at få opstillet kun een dansk liste. På 
grund af de konservatives store fordringer opnåedes ingen enighed ...

22. december. Den tyske mellemskole holdt i eftermiddags juleforestilling på "Tonhalle"; der blev opført en eventyrkomedie og deklameret en hel del, endog juleevangeliet blev fremsagt fra scenen af børn, der trådte frem foran tæppet. Alt var ægte tysk, og hvis man ikke kendte de virkelige forhold i Tonder, kunne man godt tænke sig hensat til en eller anden by i Tyskland; men heldigvis! Denne verden, man her for en time var hensat $i$, svarer lidt til de virkelige tilstande i Tyskland. Men en verden for sig havde man været $\mathbf{i}$ - en verden, som de fleste kongerigske danske ikke kender noget til. Derimod kommer tyskerne til mere og mere at kende danskernes "verden ", og man kan — særlig ved en lejlighed, som den her nævnte - ikke befri sig for spørgsmålet: "hvilke af disse to kulturer vil sejre? "Svaret er angivet ovenfor: idet den tyske kun er lidt underbygget, må den blive den svageste.

Ved julefesten på den tyske borgerskole så jeg forresten en ... elev på skolen bevæge sig frit om i salen med en matroshue, hvorpå der stod Christian den $\mathrm{X}$.

\section{5.}

26. januar. Fru Roust (lærer ved den danske folkeskole Th. Roust's hustru) fortalte mig i aften følgende lille træk om en ung pige - Y., der for et par år siden er udgået fra den tyske skole, og som nu er ansat $i$ en sæbeforretning: Der kom en pige ind $i$ forretningen og talte tysk. Y. sagde da ret skarpt: "Kan du ikke tale dansk! " Jeg bemærker kun, at da den unge pige gik i skole. var hun blandt dem, der syntes at være sig deres tyskhed bevidst. Hun sværmer vist for en mand, der er dansk, og den slags har vist sig at være afgørende også over det nationale.

1. februar. Dyrlæge Nielsen fortalte mig, at han havde været inde på "Marschbahnhofs Hotel " og var der kommet i selskab med værten (H. Jürgensen) og andre tysksindede. Talen kom til at falde på forholdene, efter at Tønder nu er blevet dansk, og flere udtalte, at de i grunden var meget tilfredse, som det gik. "Ja", sagde værten, "vi passer meget bedre til danskerne end til prøjserne, og jeg vil til at kalde mit hotel for »Hotel Danmark «. Det 
må bemærkes, at han havde fået for meget at drikke, men det må jo også erindres, at det er af fulde folk, man skal høre sandheden.

12. februar. I denne tid modtager jeg som de øvrige lærere konfirmandernes poesibøger, hvori vi anmodes om at skrive et eller andet vers e. l. til erindring. Sidste år havde jeg ved et tilfælde fundet et lille enfoldigt, letforståeligt vers, som jeg i mangel af bedre skrev $\mathrm{i}$ de fleste konfirmanders poesibøger. Da jeg $\mathrm{i}$ år skulle skrive $i$ en bog tilhørende $Z$., søn af fattige folk, så jeg, at moderen på et af de første blade havde skrevet dette vers som en erindring til sin dreng. Sidste år havde jeg skrevet det $i$ hendes datters bog. Når hun nu havde afskrevet det, vidner det jo om alt andet end uvenlige følelser over for det danske, men desuden om, at hendes kendskab dertil har været meget fattigt, siden hun netop afskrev dette vers. Havde hun ikke haft det, havde hun måske skrevet et tysk. Hvor mange danske spirer er således ikke i tidens løb dræbt af mangel på næring her i grænselandet.

14. marts. Byrådsvalget $i$ dag blev en smuk dansk sejr; efter de heldige tyske valg $i$ et par andre byer, var tyskerne her endog ved at tale om at vinde et mandat fra danskerne. Resultatet blev imidlertid, at vi vandt et mandat fra tyskerne, hvorefter stillingen er 7 tyske, 6 danske og 2 socialdemokrater. Der var en vældig valgdeltagelse, og byen var stærkt præget af valget, uden at det på mindste måde var kommet til blot antydning af sammenstød mellem dansk og tysk. Jeg var listefører i 4. distrikt og konstaterede, at langt den overvejende del af vælgerne, der mødte frem, talte dansk, hvortil de ikke mindst blev opfordret af det hidtilværende afholdte tyske byrådsmedlem, skomagermester Peter Nissen. Valgdeltagelsen var omtrent 93 pct. Interessant var det at se, at borgmester Olufsen, der af de skarpe tyskere på grund af hans dansk forsonlige sindelag og optræden var anbragt helt nede som nr. 8 på listen, fik 165 personlige stemmer, hvorover ingen kom. Det var altså en sejr for den fredelige retning; flere af tyskernes dygtige repræsentanter som bygmester Julius Hansen, direktør Neven og skomager Nissen er gået ud. Af de danske repræsentanter har dommer Gjessing nægtet at modtage valg; han ville forresten ikke være blevet valgt, da han som byrådsmedlem har været en stor skuffelse. Jeg blev valgt blandt de seks danske som Det 
radikale Venstres repræsentant. På \$Tønderhus « modtog danskerne under stor begejstring det glædelige resultat.

29. marts. Jeg var i dag til et møde angående de danskes stilling syd for grænsen. Mødet, hvortil bogtrykker Jesper Hansen havde indbudt pá interesseredes vegne, afholdtes i Fredericia og åbenbarede en stærk modsætning mellem Grænseforeningens mænd. Det kom til hårde sammenstød mellem de ledende på den ene side: Peter Grau og oberst Jørgensen og oppositionen på den anden side: Jesper Hansen, Cornelius Petersen og P. Lassen, Strukstrup. Af sydslesvigere, der var kommen til stede, kan nævnes: Tømrer Ilper fra Slesvig, købmand Andresen, Kating, og købmand Andersen fra Husum; de havde alle ordet og talte dansk, som imidlertid var tydeligt tillært og noget mangelfuldt. Mødet viste, at der savnedes en myndig mand $i$ ledelsen af arbejdet syd for grænsen, hvor vanskelighederne nu er store, hvilket imidlertid til en vis grad må anses som et gode, da den tilslutning, der nu finder sted, vil være mere ægte. Alle, ikke mindst sydslesvigerne, fremhævede også, at der ofte var forvoldt skade ved de store danske uddelinger af mad og penge, og at man ikke skulle vinde nogle på den måde, men derimod fremme et oplysningsarbejde af al kraft.

30. marts. Den danske byrådsgruppe var i dag samlet for at tage stilling til borgmestervalget, som skulle finde sted samme aften. Det kom til stærk uenighed, idet Thorvald Petersen mente, at vi ved socialdemokraternes hjælp skulle besætte borgmesterpladsen, hvortil han selv da kunne vente at blive valgt, mens bankdirektør Andresen og jeg holdt stærkt på gruppens allerede engang tagne standpunkt, nemlig at den tyske gruppe som den største skulle besætte borgmesterpladsen. Det standpunkt sluttede gruppens øvrige medlemmer sig efterhånden til, mens Thorvald Petersen, der er opfyldt af en stærk virksomhedstrang, kæmpede for sit standpunkt til det yderste, skønt han maitte vide, at det var de ovrige gruppemedlemmer klart, at han ikke mindst kæmpede for sit eget mandat. Om aftenen var byrådssalen og gangen udenfor stuvende fulde af folk, der ville overvære borgmestervalget, der også var ret spændende, for dem, der ikke vidste, at tyskerne havde sikret sig socialdemokraternes hjalp, da de nemlig ikke 
kunne stole på Olufsen, der var vraget som borgmesterkandidat. Det viste sig da også, at han stemte på sig selv; valgt blev købmand Johannes Thomsen, der takkede og overtog forhandlingen. Han talte kun tysk; men anses iøvrigt for at tilhøre den forsonlige retning.

16. april. Ved det nye skoleårs begyndelse overtog jeg $i$ dag en ny begynderklasse i dansk (4. dr. kl.) og måtte forbavses over disse niårs drenges store forhåndskendskab til dansk, hvilket kun kan forklares ved de mere og mere fordanskede omgivelser, ved den stærkere og stærkere danske atmosfære, børnene nu opvokser i. Jeg stiller hver enkelt barn, der ikke havde opgivet dansk som hjemmesprog, hvilket kun ca. femtedelen havde, det spørgsmål: "Hvor har du lært dansk «? og modtog af den første dreng svaret: "Jeg har lært dansk af Familie-Journalen". Også en stor del af de øvrige opgav, at de havde lært dansk ved læsning i danske blade; et påfaldende stort antal opgav "Vestkysten" som det blad, de læste hjemme. En dreng svarede: "Jeg har lært dansk af min bedstemor, hun bor ude på Dragonervejen.* Jeg: „Forstår din bedstemor da ikke tysk? « Han: »Jo, hun forstår det nok, men hun taler altid dansk til mig, og så synes jeg også, at jeg skal tale dansk til hende" .

Mens i tidligere år begynderklassen kun kendte enkelte ord på dansk, har den i år med største lethed kunnet gå over til at føre hele samtaler på dansk. Dette er et godt vidnesbyrd om, hvor stærkt de mange skjulte kræfter virker i dansk retning, men også et vidnesbyrd om, at det er vigtigt ikke at virke alt for aktivt $i$ national retning. Den rolige udvikling vil give sikre og gode frugter.

19. april. Ved en sammenkomst $i$ Ravsted i dag fortalte førstelærer Christensen fra Burkal mig, at den danske afdeling i B. ved det nye skoleårs begyndelse havde fået en tilgang af 4 elever, mens den tyske havde en tilbagegang på 4 , hvorefter det samlede elevtal for de to skoler er henholdsvis $46 \mathrm{og} 27$. I Store Jyndevad var en dansk fremgang på 6 og en tysk tilbagegang på 5, herefter er børnetallet i de to skoler henholdsvis 50 og 35 .

28. maj. Ved byrådsmødet $i$ går aftes forelå andragende om tilskud til det tyske bibliotek. I magistraten havde også de tyske 
medlemmer vedtaget ikke at anbefale andragendet, hvorimod Eckwerth, Todsen og Marinus Petersen i byrådsmødet stærkt anbefalede at bevilge $300 \mathrm{kr}$. På den danske gruppes vegne erklærede jeg, at danske og tyske kulturbestræbelser burde støttes af byen $i$ samme omfang, og da der allerede var nægtet tilskud til det danske bibliotek, kunne den danske gruppe heller ikke anbefale, at der ydes tilskud til det tyske. Biblioteksagen har i store træk udviklet sig således, at forst blev der, især med amtsskolekonsulent Svendsen som ophavsmand, fremsat planer til et stort dansk-tysk bibliotek; førende tyskere som Julius Hansen, Neven og overlærer Hansen gav i de forberedende moder tanken deres tilslutning; det samme var tilfældet med daværende redaktør Christensen ved "Neue Tondernsche Zeitung". De tyske vælgere har dog sikkert været imod; thi da det kom til stykket, gik tyskerne imod. Derefter oprettedes det danske bibliotek, først og fremmest ved lærer Th. Roust og amtslæge dr. Lausten-Thomsens arbejde. Da dette søgte lilskud ved byen om støtte, blev det afslået på anbefaling af Julius Hansen, der henviste til byens uheldige pengeforhold. I ovennævnte byrådsmøde henviste Atke og jeg til ovennævnte udvikling og udtalte, at på baggrund heraf kunne den danske gruppe ikke støite det tyske andragende. Socialdemokraten Bundgård udlalte, at han ikke brød sig om spørgsmålet dansk-tysk, men ville slemme imod, da der ikke på byens budget var opført det nødvendige beløb. Forslaget forkastedes herefter med̃ danskernes og socialdemokraternes stemmer. - - Det er vel første gang, at forslag om støtle til fremme af tysk kultur er blevet forkastet $i$ Tønder byråd. Skønt sagen ikke er stor, er den således dog af interesse; her har alt, hvad der var tysk, hidtil haft lov til at brede sig både under dansk og tysk styre; ved denne lejlighed er denne udvikling standset. Måske var det netop denne kendsgerning, der bevirkede lidt utilfredshed i tyske kredse, som jeg bl. a. mærkede i dag på skolen. Jeg droftede sagen med overlærer Hansen og Mar. Petersen, der vel nok særlig var overraskede over min holdning; de havde måske ikke tænkt, at jeg på grund af min særlige stilling havde vovet at tage klart standpunkt mod et tysk forslag. Jeg bemærkede bl. a., at jeg efter den forudgående udvikling i bibliotekssagen fandt det ganske uværdigt, om den danske gruppe var gået med til andragendet; det ville sige det samme som, at når tyskerne 
fløjtede, skulle danskerne danse. Overlæreren og lærer P. henviste til, at der nu var kommen et nyt byråd, og at det danske bibliotek får støtte fra amt og stat. For mig har det været ret velgørende at gå mod et tysk forslag, hvad jeg altid vil gøre, når det skyder over målet. Mine kolleger har nemlig godt af een gang for alle at få at vide, at jeg føler mig frit stillet og kun støtter tyske forslag, når jeg finder sådanne berettigede. Efter mit kendskab til disse folk vil de også blot »tage dette til efterretning «, når de tilstrækkelig tydeligt får det at vide, hvorimod de måske ville udnytte mig, hvis jeg ikke vovede at gå imod dem. "De skal sommetider have en over fingrene", som amtsskolekonsulent Svendsen siger, og hvor loyale og flinke de ellers er, er det sikkert rigtigt, for de er - som mange slesvigere $i$ det hele - ikke så lidt snu; de udnytter alle muligheder for på så umærkbar en måde at fremme små (i og for sig uskyldige) planer, som de ikke gerne kommer alt for åbent frem med; især skal vi passe på, at de ikke på en umærkbar måde misbruger dansk godmodighed. Overlærer Hansen tenderer til tider på en næsten umærkelig måde herimod. Hans interesseområde er ikke stort; han vil først og fremmest fremme det tyske skolevæsens - og derigennem tyskhedens tarv - og da han helt samler sig herom, kan han ofte arbejde med stort overlæg, på langt sigte og på en meget uskyldig måde. Det er en mand, som man først sent bliver helt klog på; men når man er det, er han og lignende folk ikke farlige, alene af den grund, at det er dem meget om at gøre at stå sig godt med deres foresatte; det gælder særlig for overlærer Hansen. Men i det stille gør han et og andet, som jeg forhen ikke ville have tiltroet ham. Forleden fik jeg således at vide, at han systematisk havde påvirket en elev, ... i hans klasse til at træde ud af Frivilligt Drenge Forbund under henvisning til, at en tysk dreng ikke kunne stå der som medlem. Resultatet blev, at drengen gik ud, men han beklagede sig over påvirkningen hos sine kammerater på skolen, blandt hvilke hverken han eller andre i mindste måde blev generet, fordi de var medlemmer af F. D. F.

9. juni. I går kom jeg hjem fra en flere dages cykletur i Mellemog Sydslesvig. Jeg cyklede over Sdr. Logum, Karlum, Læk, Risbrik, Goldelund, Joldelund, Lyngsted, Fjolde, Jydbæk til Slesvig 
og foretog herfra i de følgende dage forskellige ture. Ved grænseovergangen kom jeg til at køre sammen med en karl, der tjener i Daler, tidligere i Østerby hos gårdejer Lytsen, hvor jeg havde hørt ham omtale. Under vor samtale om sprogforholdene erklærede han, at $\mathrm{i}$ Vestre, hvor han havde hjemme, blev der næsten kun talt dansk, og han mente, at således ville forholdet også vedvarende blive; hans forældre var frisere, men da de i sin tid var kommen til Vestre havde de efterhånden fået deres frisiske sprog ombyttet med dansk. Han ville helst tjene i Danmark, endskønt lønnen nu ikke er større end i Tyskland, men »i Danmark bliver tjenestefolk da behandlet som mennesker, i Tyskland som dyr». Han talte meget om ligheden mellem folkeklasserne i Danmark, som han følte sig meget tiltalt af.

I Karlum gik jeg op på kirkegården og fandt her den dansksindede stænderdeputerede Dethleffsens gravsted, der dog - men egentlig til min overraskelse - havde gravstene med tyske indskrifter. På kirkegården traf jeg en gammel husmandskone, der talte det mest uforfalskede sønderjysk, skønt hun, da hun var kommen i skole efter 1864, havde lært tysk i skolen, hvorimod hendes søskende havde lært dansk. Hun sagde, at hun kunne ikke godt tale tysk, og når præsten, Mathiesen, tiltalte hende, skete det også på dansk; det samme var tilfældet, når præstefruen talte med hende, skønt hun var fra Kiel. Præsten havde indtil genforeningen været i Højrup. Læreren hed Petersen og havde været ansat i Bredebro og i Lund indtil genforeningen; han var født i Brarup og talte altid dansk med befolkningen. På legepladsen endog talte børnene altid dansk, hvad læreren ikke rigtig - kunne eller ville? 一 hindre. Hun fortalte mig om familien Dethleffsen på Læksgård, at den gamle Dethleffsen, den stænderdeputerede, havde talt dansk, ligeledes hans søn, der døde 1905, og dennes enke, som levede endnu og vistnok var dansksindet. Med hensyn til spørgsmålet om at være tysk eller dansk erklærede hun på sin djærve dialekt: »Ja, vi ska' sku bare tænke på, at vi kan få noget at æd' og ikke bryde os om spørgsmålet dansk eller tysk «. Hendes livssyn var, som iøvrigt de flestes, jeg traf på denne rejse, meget materialistisk, men netop herud fra synes hun at mene, at det måske havde været bedre at komme til Danmark, for hun havde hørt, at fattige folk der ikke interesserede sig for politik; man 
kunne godt være dansk uden at blive generet, bare de pågældende var » rolle folk». Som "ægte dansker" anviste hun mig den gamle Carsten Thomsen nede $i$ byen, han havde gået $i$ dansk skole før $64 \mathrm{og}$ holdt Flensborg Avis «. På vejen ned til ham spurgte jeg både unge og gamle om vej og fik udmærket svar på dansk. Carsten Thomsen var ude $\mathrm{i}$ mosen, og jeg fik således kun talt med hans kone, der meddelte mig væsentlig de samme oplysninger, som den gamle på kirkegården; hun fortalte, at hendes mand den følgende søndag (d. 7. juni) skulle til dansk årsmøde i Flensborg. På væggen hang et billede af ham fotograferet sammen med kongen ved genforeningsbesøget $\mathrm{i}$ Tønder. Billedet var taget af bagermester Thorvald Petersens datter, og hans sønner i Amerika havde ladet det forstørre.

Derfra cyklede jeg igennem den nærliggende plantage til Læk. På vejen traf jeg en stor dreng på cykle; han hørte hjemme i en gård i nærheden og talte udmærket sønderjysk. Da vi nærmede os gården, blev han på dansk anråbt af sin broder, og de to talte nu sammen på dansk, hvilket sprog også faderen, der hed Peter Holländer, brugte. Da han hørte, at jeg skulle til Læk, bad han uden at vide, hvem jeg var, mig om at gå ind til hjuler Jessen i Læk og sige til ham, at han hurtigst skulle have de otte bestilte stålstolper til sin stald. Det lovede jeg, og vi kom i snak. Han bad mig imidlertid med indenfor og fortalte mig, at det var slemt med de store skatter i Tyskland, men »i Danmark var det vel ikke bedre", mente han, "for der var kronerne jo meget knappe«. Det havde han altså også lært at sige. Jeg skulle nu endelig høre hans dreng, som jeg havde cyklet sammen med, spille klaver. »Ja, vi har nemlig et klaver; det købte jeg i inflationstiden, da vi bare skulle sørge for at få noget ud af vore penge", drengen spillede da nogle melodier, som han havde lært hos præstefruen. Sproget i gården syntes at være dansk.

I Læk hørte jeg ikke noget dansk, hverken på gaderne eller under et ophold i en gæstgivergård. I Stadum spurgte jeg en midaldrende mand om vej og fik en længere forklaring på godt dansk. Ved Risbrik kom jeg i tale med en tilsyneladende 18-19 års bondepige, der skulle til at malke. Hun talte med lethed sønderjysk, men erklærede, at det havde hun lært under et tjenesteophold $i$ Tørsbøl; de unge, der på egnen, kunne ellers ikke tale dansk, men 
vel forstå det; de havde lært det af de gamle. I Goldelund talte jeg med en ikke gammel mand (måske 50 år), han havde dansk hjemmesprog, hvad han erklærede, mange havde $\mathrm{i}$ hans alder; de unge derimod forstod det kun, og han mente, at dansk ville dø ud, fordi ingen talte det til børnene; de kommende generationer ville højst kunne forstå, ikke tale dansk. I Joldelund talte jeg med en midaldrende mand, sproget godt sønderjysk, som han fortalte, at alle $\mathrm{i}$ hans alder kunne tale; de unge kunne blot forstå det; han mente også, at dansk efterhånden ville blive ukendt; mens vi stod ved hans gård, kom et par unge karle fra marken; de tog del i samtalen, men på tysk. Manden, der talte plattysk med dem, klagede over de høje skatter, men forøvrigt havde også han hørt, at kronerne var meget knappe i Danmark.

I Neukrug spiste jeg, mens kromanden underholdt mig. "Jeg kan nok tale dansk ", erklærede han, da han hørte jeg var fra Danmark. Samtalen mellem os førtes dog på tysk. Hans dansk havde han vist mest lært ved markederne i Tønder, i hvert fald sagde han med synlig glæde, da han fortalte herom: "Giv vos så en punch, mor". Han udtrykte iøvrigt, idet han antagelig gik ud fra, at jeg som værende fra Tønder var tysk, sin forvisning om, at Nordslesvig vel nok blev tysk igen. På hans spørgsmål om, hvordan vi nu kunne enes med danske i Tønder, kunne jeg blot sige, at danskerne ikke var så slemme. Hans gamle far levede endnu, men var i øjeblikket ikke til stede; han havde gået i dansk skole i 50erne og kunne huske pastorerne Muhle og Hansen i Fjolde. I den stille sommeraften kørte jeg nu over Fjolde, Bandelum, Solbro, Arenholt - alt helt tabt sprogområde - til Slesvig, hvortil jeg kom kl. 11 aften og tog ind på "Slesvighus ". Om Iørdagen cyklede jeg ud langs Danevirke og kom til Ellingsted, hvor volden hører op. Her talte jeg med en tørvegraver, der vidste god besked med planerne om oversvømmelserne, der herude skulle indgå som et led i Danevirke-stillingen i 1864. Om den danske tid fortalte han kun godt, danskerne var flinke. "Hvordan var folk så tilfredse, da prøjserne kom?" » $\AA$, det gik egentlig godt; prøjserne var også flinke folk. Da danskerne var gået bort fra volden, kom prøjserne herover fra Reide, hvor de havde ligget; de gik ind i husene for at se efter danske soldater, indad den ene dør og udad den anden, uden at gøre noget ondt". I 1919 var der mange, der hernede 
mente, at de nu blev danske igen, og det troede han ikke, der var bleven ufred over. Han syntes iøvrigt at vare en mand, der tog livet med stor sindsro, og for hvem sporgsmålet dansk eller tysk var ret ligegyldigt og ubetydeligt. Han gav mig anvisning på en gammel mand ved navn Koberg, der boede i Ellingsted. Han havde været dansk soldat og været med i 64 . Ham besøgte jeg da næste dag; jeg cyklede igennem Dyrehave forbi lazarettet, Ziegelei og over Husby, hvor de store mosestrækninger snart breder sig for én. Koberg var helt op i firserne, men rask og åndslivlig, klar i sin fortælling. Alt vedrørende krigen huskede han i mindste enkeltheder; kun nu og da kneb det for ham at genfremkalde et eller andet navn. Det var ham tydeligt en glæde at fortælle om alt vedrørende krigen, skønt jeg ikke fik det indtryk, at han var dansk, men som alle, jeg traf på her, mindre nationalt interesseret. Han var født i Selk og blev 2. januar 1863 indkaldt som husar til Jagersborg. Rejsen dertil gik over Kiel - Korsør til København. Da han kun kunne tysk, havde han enkelte vanskeligheder med sproget undervejs. I København blev han sammen med andre sydslesvigere ført til Jagersborg for at uddannes. Hans eskadronchef hed Neergård; regimentet bestod af sydslesvigere og sjællændere, hvoriblandt var kulsviere. Sjællenderne var fordringsfulde, hvorfor befolkningen under indkvarteringer hellere ville have slesvigere - trods sproget. Koberg lærte snart at tale dansk og kunne endnu tale en del, hvorimod han ikke så godt kunne læse det. I oktober 1863 var han med til kongemanøvre i Sydslesvig og huskede fra den tid Frederik den 7. Da denne døde, var de på vej til Jægersborg, men ved Nyborg fik de ordre til at gå tilbage til Danevirke. Forst kom hans afdeling helt ned til Neumünster, men gik over Itzehoe tilbage til Ellingsted, hvor den kom til at ligge. Han kunne huske general Wilster, der lå i Frederiksstad. Engang skulle Koberg hen til ham; han kom ud ad døren, og spurgte, hvem han var og hvorfra, og derefter om han kunne tale dansk. "Ja, det kan jeg nok, hr. general", svarede da Koberg (dette gengav han pâ dansk $i$ vor samtale $i$ en meget smuk udtale, ligesom andet, hvad han gengav på dansk); de Meza så soldaterne aldrig der vestude, men han havde set ham ved manøvrerne i 1863. Da det blev frost, skulle soldaterne hele tiden lave vâger $i$ isen. På mit spørgsmål om, hvordan de fik besked om en eventuel retræte, 
fortalte han, at der så skulle tændes et rødt lys på højene ved Husby. Da de virkelig så det og fik ordre til at gå tilbage, kunne ingen af soldaterne forstå det. Herefter kom han til at ligge på Als; han var ikke med ved Dybbøl, men havde været ude i nogle forpostkampe foran stillingen. Efter krigen blev han hjemsendt fra Kabenhavn; han havde endnu sit hjemsendelsespas og øvrige danske militærpapirer. Den danske tid mellem krigene erindrede han godt; han havde haft ældre brødre med ved Fredericia og Isted, selv kunne han fra sine drengeår erindre noget om påskeslaget ved Slesvig. Som større dreng havde han tit måttet køre ind til Slesvig med landbrugsprodukter; han kom da ofte på Gottorp, hvorfra han kunne huske en kokkepige, der hed Frederike. På disse ture kom han også til madam Esselbach, hvor der ofte var så mange danske officerer forsamlet. Desuden fortalte Koberg, at han kom med varer til "prinsessen af Norge", der boede i et af palæerne på Friederichsberg. Af de danske embedsmænd kunne han blandt andet huske politimester Jørgensen og herredsfoged Blauenfeldt i Flekkeby. Den sidste, mente han, var meget ufornuftig, da han gerne straffede for de mindste småting. Han stod derfor $i$ et spændt forhold til befolkningen. Der var en mand, der hed Mauw, der gerne ville drille ham. Engang skulle Mauw i fængsel; han bad da Blauenfeldt gå foran og vise ham ind; det gjorde Blauenfeldt også, og Mauw slog da celledøren i for ham, så at han blev lukket inde, og Mauw løb ud i byen og fortalte historien til fornøjelse for befolkningen. Næste dag blev han naturligvis igen arresteret. En dag gik Mauw op til Blauenfeldt og spurgte: "Hat Wind und Wasser seinen freien Lauf «. Ja, mente Blauenfeldt da, og Mauw forrettede da sin nødtørft på gulvet i kontoret. På mit spørgsmål om, hvordan befolkningen $i$ det hele var tilfredse i den danske tid, svarede Koberg, at de havde været godt tilfredse, »aber dann wollte Dänemark ja uns incorporieren, und das wollten wir ja nicht «. Gendarmerne var gennemgående flinke, »aber stark dänischgesinnt ". Koberg fik nu den danske veterangave og meddelte endelig til sidst, at der også i Ellingsted var nogle, der kunne læse dansk og var dansksindede, og hvorfor de var det, kunne han egentlig ikke forstå. På vejen tilbage til Slesvig kørte jeg gennem Isted-terrænet og traf her en anden gammel veteran. Det er meget betegnende for, hvorledes et slagord kan 
bide sig fast, at han, da jeg under samtalen spurgte, hvorfor sydslesvigerne ikke ville være danske, erklærede: "Weil Dänemark wollte uns incorporieren «. Og han var dog dansksindet, for da jeg spurgte ham, om ikke mange havde været utilfredse med den danske tid, erklærede han: »Ich war jedenfalls nicht unzufrieden; ich bin danischgesinnt". Med hensyn til det danske arbejde $i$ Slesvig fik jeg det indtryk, at der var almindelig tilbagegang fra inflationstidens tilsyneladende fremgang. Det ville værten (særlig fru Ingversen) heller slet ikke skjule; hun mente, at der nu højst var 35 medlemmer $i$ ungdomsforeningen og et par hundrede voksne medlemmer $i$ »Slesvigsk Forening ". " Men bare der var hundrede gode, skulle vi være glade", sagde hun. Lærer Christensen udtalte sig i samme retning; det danske bibliotek blev ikke benyttet meget, hverken af børn eller voksne, og til dansk undervisningen er der ingen god tilslutning ....

De store skatter trykker hårdt på »Slesvighus", hvis store sal måske skulle lejes ud til biografteater. Søndag den 7. juni var der stor "Turnfest « i Slesvig, der vel nok havde et vist politisk anstrøg; et par gange kom der optog med musik gennem byen, og uden for "Slesvighus" blev "Schleswig-Holstein meerumschlungen" stadig spillet uden iøvrigt, at deltagerne foretog sig noget uvenligt.

13. juni. Jeg var $i$ dag en time nede $i$ anlagget med nogle piger og drenge for at lege; da pigerne havde leget nogle tyske lege, spurgte jeg, om de ikke kunne »to mand frem for en enke". Det kunne de nok og begyndte straks at lege den på dansk.

14. juni. Amtsudstillingens åbning sætter i dag sit festlige præg på byen - og præget er dansk. Der er vist flere flag hejst end før, og alle de tusinder af mennesker, der med tog og bil strømmer til byen, er jo fra det danske opland, så der næsten kun høres dansk tale. Over middag kom kongen; han stod af bilen ved Sønderbro, hvor der var sort af mennesker, danske og tyske. Efter at udstillingen var beset, tog kongen opstilling ved broen, mens det store håndværkertog drog forbi; forrest kom skyttekorpset med fuld musik i spidsen; korpsets officerer gjorde korrekt honnør for kongen under forbimarchen; medlemmerne er overvejende tyske; dette træk er derfor betegnende for den gode, loyale stem- 
ning. Bagefter kom de tyske ringridere og Møgeltønder ringriderkorps med Danebrog i spidsen; herefter kom en lang række håndværkervogne repræsenterende de forskellige håndværk. Udstillingen blev nu offentligt tilgængelig og blev den første dag besøgt af over ti tusinde personer. Den nationale betydning er utvivlsom, overalt vajede danske flag og lyste danske indskrifter såvel fra danske som tyske udstillinger. Og Tønder-drengene, der gik og solgte lodsedler, fik den dag brug for deres dansk. Man fik her et talende bevis for, hvad det betyder for Tønder by i sproglig henseende, at hele omegnen er dansktalende.

15. juni. Amtsfuldmægtig Florander fortalte på Svendsens kontor, at formanden for de tyske ringridere, landmand Carl Sønnichsen (ved Sonderbro), med megen tilfredshed havde fortalt om sin samtale med kongen på udstillingen. Det havde glædet ham, som han sagde, at "han kunne bruge landsens sprog i samtale med kongen ". Forresten fortalte byrâdsmedlem, lærer Atke (statsskolen), mig, at bygmester Julius Hansen engang havde sagt, at skyltekorpset med glæde ville paradere for kongen. "Nå, det ville nok? " "Ja naturligvis ", svarede han, "skyttekorpset har jo paraderet for så mange danske konger ". I middags mødte jeg bagermester Lassen pă gaden, han fortalte straks om, hvor glad hans gamle far havde været for Danebrogs-korset, som kongen i gâr havde givet ham pâ udstillingen ....

Mens vi talte sammen, kom garnisonen i fuld udrykning forbi os med dragonerne i spidsen, to musikkorps og faner, ført af oberstløjtnant Obel; det er forste gang, jeg igennem Tønder by har set et så stort militært optog; beboerne viste alle megen venlig interesse.

18. juni. Overlærer Hansen fortalte i formiddags, at redaktør Bødewadt den foregående aften havde været hos ham og beklaget sig over, at den unge lærerinde ved den tyske mellemskole, frk. Krogh, havde ladet børnene $i$ en dansktime lese en skildring i den danske læsebog af oproret i 1848. Jeg må også undre mig over, at hun, der i hvert fald skal gå for at være tysk, kunne være såi uforsigtig at lade noget sådant oplæse.

19. juni. I går aftes vakte det ophidselse blandt nogle tyske og beklagelse blandt alle danske, at sangeren Saxtorph Mikkelsen 
bl. a. sang en sang om tyskernes kirkeklokkerov i Belgien i verdenskrigen. Det var en lille mislyd $i$ udstillingen, ved hvilken danske og tyske ellers har samarbejdet udmærket.

24. juni. Efter opfordring af dr. Lausten Thomsen forestod jeg ved hjælp af børn fra den tyske skole salget af fredsmærket. Børnene viste stor interesse for sagen, og flere af dem fik mere end een gang udsolgt. I intet tilfælde satte forældrene sig imod, at deres børn var med ved arbejdet. En søn af sognefoged Paysen i Sæd solgte et meget stort antal og erklærede, at han kunne have solgt et meget større antal, hvis han havde haft flere; han ville da have cyklet til Rørkær og Ubjerg; nu solgte han 150 i det overvejende tyske Sæd og kom endda ikke ned til grænsen.

25. juni. En dreng i $6 \mathrm{kl}$. fortalte mig i dag om en bog, han havde lånt, og udtalte: "Den er god nok, men meget usandsynlig". Lektor H. V. Clausen, der har været i Tønder i disse dage som censor $i$ historie ved statsskolen, morede sig over at høre, at Tønderdrengene i den tyske skole var så godt inde i det danske sprog, at de anvendte den slags udtryk.

5. juli. I middags traf jeg redaktør Petersen-Høkkelbjerg ("Tønder Amts Dagblad «), der fortalte mig, at der inden for ringriderkorpset havde været nogen misstemning blandt de mest tyske over, at formanden, Carl Sønnichsen, havde kommanderet på dansk ved kongemodtagelsen. Sønnichsen havde da truet med at udmelde sig; og direktør Neven ville da også gå. Herefter måtte de yderligtgående falde til føje.

6. juli. Den tyske mellemskole har haft skoleudflugt til Silkeborg (2 dage); viceinspektør Elholm fortalte med tilfredshed om turen; de havde været indkvarteret $i$ en større, meget moderne proprietærgård, hvor børnene havde haft den største frihed og var blevet meget venligt og taktfuldt behandlet af ejeren. På en af de små dampere skulle der derimod fra de medrejsende være faldet en uheldig bemærkning.

7. juli. I formiddags var jeg ude hos en familie K. i Carstensgade, hvis datter går $\mathrm{i}$ den tyske skole, jeg overbragte moderen et fripas for datteren til en sommerferierejse til Sjælland. Over sofaen hang et billede af ministeriet Stauning, $i$ sofaen lå en pude 
med påskriften: "Nur eine Viertelstunde ", dansk og tysk i skøn forening. Moderen, der var meget taknemlig for frirejsen, fortalte om en voksen søn, der arbejdede som slagter i Ruds Vedby på Sjælland; han var så tilfreds med danske forhold, særlig med behand. lingen af undergivne, at han havde udtalt sig bestemt mod at komme tilbage igen.

15. september. For en anden lærer havde jeg $i$ dag en time $i$ en 3. drengeklasse, der endnu ikke har dansk. Jeg spurgte en dreng, om han kunne dansk; det kunne han nok, for hjemme læste han »æ blad " og "Knold og Tot «; "æ blad « var »Vestslesvigs Tidende».

26. september. I dag deltog byrådet $\mathrm{i}$ den årlige høstfest på Gørrismark. Det var bemærkelsesværdigt, hvor meget dansk der blev talt af de tyske deltagere, også mellem hverandre indbyrdes, om aftenen spillede fire tysksindede (borgmester Thomsen, invalidekonsulent Fr. Andresen, tandlæge Iversen og slagtermester Erich Petersen) kort sammen, og samtalen fortes udelukkende på dansk. Denne sammenkomst formede sig ligesom alle lignende under den bedste forståelse mellem danske og tyske.

28. september. I går aftes var jeg til sølvbryllup hos lærer $\mathrm{X}$. Hen på aftenen spillede og sang de voksne døtre, midt i de tyske sange istemte de pludselig også danske, f. eks. "Flyv, fugl, flyv * og andre, og sang dem meget smukt. Lærer $\mathrm{X}$ er sydslesviger, en godmodig mand, men stående danske forhold ret fjern; jeg blev derfor så meget mere glædelig overrasket over denne lille begivenhed. De unge piger, der indfører sådan noget, har opholdt sig i Helsingør og København; . . . dette er et udtryk for, at det er de unge, der bestemmer fremtiden.

28. oktober. Sammen med amtsskolekonsulent Svendsen har jeg i dag været til en sammenkomst på "Folkehjem " i Åbenrå, hvor også Lebeck og amtsskolekonsulent Mortensen var til stede. Der skulle drøftes det, Svendsen kalder oprettelsen af en Præmaturinerklub $\approx$, d. v. s. en lille sammenslutning af mænd i Nordslesvig, som har lejlighed til på første hånd at iagttage nationalitetskampen i alle dens foreteelser. Sammenkomsten skal ikke på nogen måde have nogen foreningskarakter, men forhandlingerne skal være strengt fortrolige. Det besluttedes at indkalde til et sådant møde $i$ indeværende efterår. Efter aftensmaden gik vi over til 
Lebecks og drak kaffe; her gav Svendsen på grundlag af en skriftlig fremstilling, han havde fået fra Flensborg, oplysning om den mindretalsordning, der kan forventes indfort for danskerne syd for grænsen og ventes at blive offentligt bekendtgjort d. 1. januar. Der bliver heldigvis ikke tale om autonomi. Den tyske ordning bliver $i$ det hele og store efter samme principper som vor, men absolut mindre frisindet, særlig den private skole får syd for grænsen en afgjort mindre heldig stilling end hos os. Dog vil ordningen altid have sin værdi, især for sprogets opretholdelse; hvad sådan en officiel anerkendelse og afstivning af det danske sprog i Mellemslesvig vil betyde, ser man bedst, når man tænker på, med hvilke uendelig ringe midler det hidtil har varet opretholdt. Endelig må det ventes, at en ordning vil skabe mere ro ved grænsen; formentlig vil tyskerne hos os blive noget mere afdæmpede i deres krav om autonomi - for dem må der formentlig komme en hel ny indstilling.

10. november. Svendsen fortalte i eftermiddags, at amtsassessor Steemann engang besøgte sine adelige slægtninge på et gods i Holsten, hvor også prins Meinrich af Prøjsen (kejserens broder) var til stede. Da Steemann blev forestillet for prinsen, sagde han, der troede, at Steemann var tysk nordslesviger: "Ah, aus Tondern. ja das wollen wir ja bald wieder holen «. Da fadæsen blev prinsen klar, måtte senere en kavaler hen og glatte ud.

12. november. Lærer Gläser, der efter at have gennemgået årskursus i dansk på Statens Lærerhøjskole nu også har taget studentereksamen, i hvilken anledning han i efteråret har opholdt sig nogle uger i København, fortalte mig i dag, at en yngre tysk lærer havde udtalt sin forundring over, at han så stærkt orienterede sig i dansk retning; "han har fået stærke danske sympatier". Gläsers "linie" ændres ikke af den slags udtalelser; han har indmeldt sig til den filosofiske prøve ved Københavns universitet. Kollegerne ved skolen er alt dette ikke behageligt, men i det ydre mærker man ikke noget.

Karetmager F. . . , hvis datter S. . . jeg efter hendes udgang af den tyske skole her skaffede et ophold på Holsted efterskole, var her $i$ aften for at tale med mig om datterens optagelse på seminariet; han fortalte mig da, at overlærer Hansen havde hentydet til, 
at der kunne opnås understottelse fra tysk side, mod at datteren så blev lærerinde ved en tysk skole. "Det afslog jeg", sagde F. . . . til mig, »for jeg ved ikke, hvad De mener om mig, men jeg er dansk, og det er S. . . også blevet i afgjort grad, efter at hun har været på Holsted efterskole; derfor ønsker hun heller ikke at blive lærerinde ved en tysk skole, hvad jeg heller ikke gerne ser «. Denne familie var utvivlsomt - uden iøvrigt at tænke nærmere over problemet - tysksindet efter genforeningen, da den tilflyttede fra Altona.

15. november. I et lærermøde i eftermiddags faldt talen atter på de mange fejl i tysk retskrivning. Fru Grandt udtalte den formodning, at forholdet stod i forbindelse med, at børnene læser for meget dansk litteratur. "Børnene vil jo kun læse dansk; er det ikke muligt, at vi kan få nogen god tysk børnelitteratur? " Hertil svarede overlærer Hansen, at han skulle fremlægge nogle bogfortegnelser, men han tvivlede iøvrigt om, at der kunne findes nogen tysk litteratur, der egnede sig. Det var sikkert en del af lærerne behageligt, at spørgsmålet blev bragt frem, fordi de vel $i$ det stille har ærgret sig lidt over den stærke tilstrømning af børn til det danske bibliotek; enkelte af dem udtalte da den formodning, at børnene fik for mange bøger, således at de forsømte deres skolearbejde. Til de forskellige udtalelser svarede jeg med at henvise til, at en elev som regel kun fik to bøger om ugen og til betydningen for danskundervisningen, at eleverne læser god dansk litteratur. Iøvrigt gjorde jeg opmærksom på, at jeg naturligvis efter forhandling med klasselæreren gerne ville indskrænke bogudlånet for en enkelt elev, der viser sig meget efterladende med sit skolearbejde. I den forbindelse kunne jeg gøre opmærksom på, at jeg allerede havde nægtet et par elever danske bøger, fordi deres skolearbejde til mig ikke havde været tilfredsstillende. Jeg kunne forresten navngive et par elever, som jeg havde nægtet at låne, og som derefter var begyndt at låne bøger $\mathrm{i}$ det offentlige danske bibliotek i Østergade. Denne meddelelse gjorde sikkert et lidt ubehageligt indtryk, der jo yderligere understregede den stærke trang og lyst til dansk læsning. Meningsudvekslingen førtes i en rolig og venskabelig tone. I mit indre følte jeg en stærk glæde over den kraft, som dansk kultur i det stille viser sig i besiddelse af. For- 
øvrigt er ingen mere ivrig til at trænge ind på mig for at få mere end de to bøger end netop fru Grandts fjortenårige datter, der går i skolens ottende klasse. I det hele har interessen for dansk læsning i denne vinter været stærkere end nogen sinde før; også redaktør Bødewadt's søn har meldt sig som låner.

30. november. I eftermiddags holdtes den første sammenkomst til drøftelse af den nationale stilling. Til stede var $H$. P. Hanssen, Lebeck, Nicolai Svendsen, stiftamtmand Haarløv, biskop Ammundsen, bibliotekar Jacob Petersen, amtsskolekonsulenterne Mortensen og Nielsen, Jefsen Christensen og amtslæge, dr. Lausten Thomsen samt jeg. Lebeck gav en redegørelse for stillingen bygget på statistisk materiale, som han har samlet på de senere år. Af redegørelsen, der som alle forhandlinger var strengt fortrolige, fremgik, at tyskerne $i$ de truede egne " ejer størstedelen af jorden, hvilket særlig kan blive farligt, hvis de finder på at udnytte den danske husmands- og udstykningslovgivning, idet de ved hjælp af den kan foretage en tysk kolonisation. Der var enighed om at fortsætte med lignende sammenkomster, således at praktiske spørgsmål kan tages op til behandling og løsning.

12. december. I går aftes holdt den tyske mellemskole forældremøde på "Skyttegården ". Overlærer Hansen fortalte mig i dag, at værten (Buckow) havde pyntet kaffebordene med tyske flag (det gamle). Da mellemskolens leder, viceinspektør Elholm henimod aftenstid tilfældig kom ind i salen, gav han straks ordre til at fjerne flagene, hvilket skete, men gav anledning til, at et par tilstedeværende tyske håndværkere lavede stort spektakel, og de truede med at protestere højlydt under mødet, hvad dog ikke skete.

22. december. I forståelse med overlæreren har jeg i disse dage i klasserne foretaget den sædvanlige uddeling af julehefter, som tilsendes mig fra Sprogforeningen. Børnene lægger meget tydeligt for dagen, hvor glade de er for disse hefter; allerede $i$ begyndelsen af indeværende måned begyndte de at spørge, om de også $i$ år fik julebøger; flere af dem fortalte, at de endnu havde de hefter, de havde fået tidligere år. I de sidste dage har flere elever endog sendt mig julekort med bøn om en julebog.

23. december. Nogle penge, der var indkommen ved en julegodt- 
gørenhedsfest blev igår aftes fordelt på *Skyttegården * til et stort antal danske og tyske børn; overlærer Novrup talte til børnene på dansk, lærer Gläser på tysk; der blev sunget julesalmer på begge sprog. Alt var idyl - ingen gnidning, hvad der var meget tilfredshed med, ikke mindst fra tysk side; byrådsmedlem Fr. Andersen og sadelmagermester Fr. Roost (tyske) udtalte, at de håbede, at uddelingen også $\mathrm{i}$ fremtiden måtte ske på samme smukke måde.

(Fortscttes). 